2. To: (Receiving Organization)

Distribution

5. Proj./Prog./Dept./Div.:

Spent Nuclear Fuel Project

8. Originator Remarks:

This document is being distributed for approval and release.

3. From: (Originating Organization) Nuclear Safety

6. Design Authority/ Design Agent/Cog. Engr.:

L. J. Garvin III

11. Receiver Remarks: 11A. Design Baseline Document? [X] Yes $5 / 21 / 97$
4. Related EDT Ho.:

607687

7. Purchase order No.:

$\mathrm{N} / \mathrm{A}$

9. Equip./Component No.:

N/A

10. Systen/Bldg./Facility: CSB/CVD

12. Major Assm. Dwg. No.: N/A

13. Permit/Permit Application No.: $N / A$

14. Required Response Date: $05 / 09 / 97$

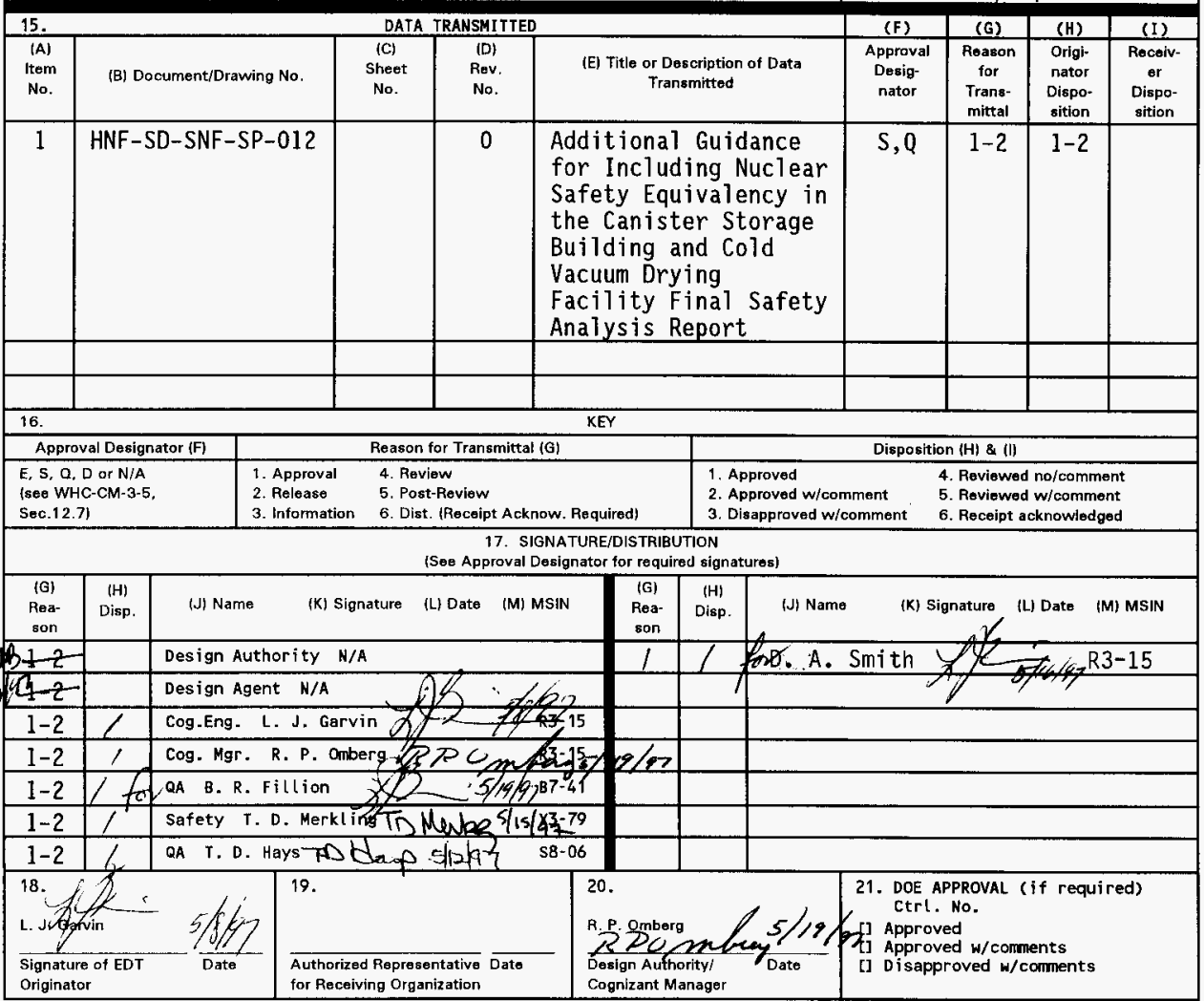




\title{
Additional Guidance for Including Nuclear Safety Equivalency in the Canister Storage Building and Cold Vacuum Drying Facility Final Safety Analysis Report
}

\author{
L. J. Garvin \\ Fluor Daniel Hanford, Inc., Richland, WA 99352 \\ U.S. Department of Energy Contract DE-AC06-96RL13200 \\ EDT/ECN: 607687 \\ Org Code: 2T640 \\ B\&R Code: EW31354

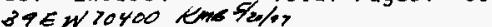 \\ UC: 620 \\ Charge Code: LG070 \\ Total Pages: 39
}

Key Words: Nuclear, Safety, Equivalency, Canister Storage Building, Cold Vacuum Drying Facility, Analysis

Abstract: This document provides guidance for the production of safety anaTysis reports that must meet both DOE Order 5480.23 and STD 3009 , and be in compliance with the DOE regulatory policy that imposes certain NRC requirements.

TRADEMARK DISCLAIMER. Reference herein to any specific commercial product, process, or service by trade name, trademark, manufacturer, or otherwise, does not necessarily constitute or imply its endorsement, recommendation, or favoring by the United States Government or any agency thereof or its contractors or subcontractors.

Printed in the United States of America. To obtain copies of this document, contact: Document Control Services, P.O. Box 950, Mailstop H6-08, Richland WA 99352, Phone (50́9) 372-2420;

Fax (509) 376-4989.
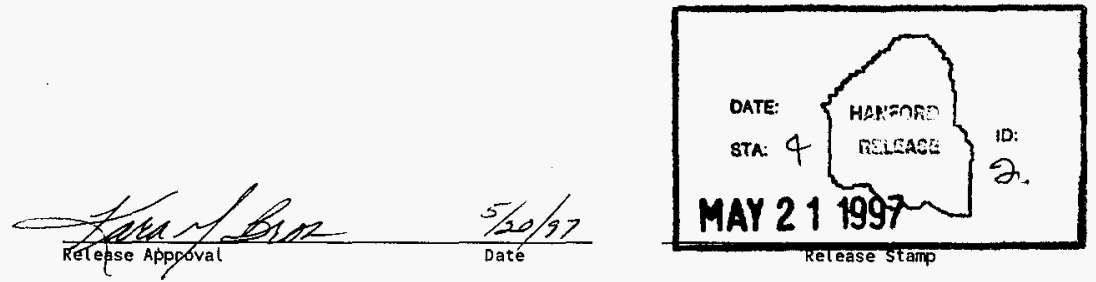

Approved for Public Release 


\title{
ADDITIONAL GUIDANCE FOR IMCLUDING NUCLEAR SAFETY EQUIVALENCY IN THE CANISTER STORAGE BUILDING AND COLD VACUUN DRYING FACILITY FINAL SAFETY NALYSIS REPORTS
}

\author{
HWF-SD-SNF-SP-012 \\ Revision 0
}

May 1997 
HNF-SD-SNF-SP-012 REV 0

This page intentionally left blank. 


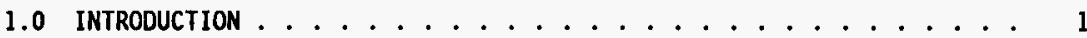

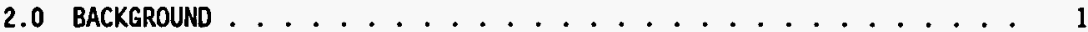

3.0 IMPLEMENTATION . . . . . . . . . . 3

3.1 CANISTER STORAGE BUILDING . ............ 3

3.2 COLD VACUUM DRYING FACILITY $\ldots \ldots \ldots$

4.0 REFERENCES ..................... 5

\section{LIST OF TABLES}

1 Items in Regulatory Guide 3.48 that are Unique to the Storage of Spent Nuclear Fuel ................ . . T-1

2 Items in Title 10, Code of Federal Regulations, Section 72.24, that are Unique to the Storage of Spent Nuclear Fuel . . . . . . . T-9

3 Information to be Added to the Final Safety Analysis Report for the Canister Storage Building that is not Required by DOE Order 5480.23 or by DOE-STD-3009-94 but is Needed to Implement Nuclear Safety Equivalency . . . . . . . . . . . . . . T-11

4 Items of Regulatory Guide 3.26 that are Unique to Fuel Conditioning .................. . . . . . . . . . .

5 Information to be Added to the Final Safety Analysis Report for the Cold Vacuum Drying Facility that is not Required by DOE-STD-3009-94 and that is Unique to the Conditioning Process . . . . T-25 
HNF-SD-SNF-SP-012 REV 0

\section{LIST OF TERMS}

$\begin{array}{ll}\text { CSB } & \text { Canister Storage Building } \\ \text { CVDF } & \text { Cold Vacuum Drying Facility } \\ \text { DOE } & \text { U.S. Department of Energy } \\ \text { FSAR } & \text { final safety analysis report } \\ \text { NRC } & \text { U.S. Nuclear Regulatory Commission } \\ \text { SNFP } & \text { Spent Nuclear Fuel Project }\end{array}$


HNF-SD-SNF-SP-012 REV 0

\section{ADDITIONAL GUIDANCE FOR INCLUDING NUCLEAR SAFETY EQUIVALENCY IN THE CANISTER STORAGE BUILDING AND COLD VACUUH DRYING FACILITY FINAL SAFETY ANALYSIS REPORTS}

\subsection{INTRODUCTION}

This document identifies information that is to be included in the Canister Storage Building (CSB) and Cold Vacuum Drying Facility (CVDF) Final Safety Analysis Reports (FSAR) in addition to the information required by U.S. Department of Energy (DOE) Order 5480.23, Nuclear Safety Analysis Reports, and DOE-STD-3009-94, Preparation Guide for U.S. Department of Energy Nonreactor Nuclear Facility Safety Analysis Reports. For the CSB, this additional information, unique to spent nuclear fuel storage, is that required by Title 10, Code of Federal Regulations, Part 72, "Licensing Requirements for the Independent Storage of Spent Nuclear Fuel and High-Level Radioactive Waste, "Section 72.24, "Contents of Application, Technical Information" (10 CFR 72), and by U.S. Nuclear Regulatory Commission (NRC) Regulatory Guide 3.48, Standard Format and Content for the Safety Analysis Report for an Independent Spent Fuel Storage Installation or Monitored Retrievable Storage Installation (Dry Storage) (NRC 1989). For the CVDF, this additional information, unique to the conditioning of the spent nuclear fuel, is that required by Regulatory Guide 3.26, Standard Format and Content of Safety Analysis Reports for Fuel Reprocessing Plants (NRC 1975). Deviations from the content specified in DOE Order 5480.23 or DOE-STD-3009-94 shall be evaluated for compliance with the content requirements of the applicable NRC regulatory guide.

\subsection{BACKGROUND}

In Memorandum EM-36-3.1.6.7, Concurrence with the K-Basins Spent Nuclear Fuel Project Policy on Nuclear Safety Requirements (Grumbly 1995), (hereafter referred to as the Policy), DOE established the requirement that new Spent Nuclear Fuel Project (SNFP) facilities achieve "nuclear safety equivalency" to comparable NRC-1icensed facilities. For that Policy (Grumbly 1995), nuclear safety equivalency was defined as conformance with

- Technical requirements that meet the nuclear safety objectives of the NRC regulations for fuel treatment and storage facilities, including requirements regarding radiation exposure limits, safety analysis, design, and construction

- Administrative requirements that meet the objectives of the major elements of the NRC licensing process, including formally documented design and safety analyses, independent technical review, and opportunity for public involvement.

Technical requirements, in the context of the Policy (Grumbly 1995) and as interpreted by the Regulatory Requirements Team, are the design and 
construction measures (as opposed to preoperational or operational measures) that are mandated by the NRC regulations. In addition, the Policy specifically excludes those requirements that address only environmental, Occupational Safety and Health Administration, chemical accident safety, and other non-nuclear safety issues (Grumbly 1995).

NRC guidance that provides acceptable means to implement the regulations was defined as optional rather than mandatory in the Policy (Grumbly 1995). However, as a prudent step in implementing the Policy's objectives, NRC guidance that may have direct relevance to SNFP Path Forward activities (e.g., NRC Regulatory Guide 3.60, Design of an Independent Spent Fuel Storage Instaliation [Dry Storage] [NRC 1987]) was reviewed and evaluated for incorporation of additional requirements believed warranted to achieve nuclear safety equivalency. two reports:

Implementation of the Policy (Grumbly 1995) for the CSB is documented in

- WHC-SD-SNF-DB-002, Spent Nuclear Fuel Project Path Forward, Nuclear Safety Equivalency to Comparable NRC-Licensed Facilities (Garvin 1996b)

- WHC-SD-SNF-DB-003, Spent Nuclear Fuel Project Path Forward, Additional NRC Requirements (Garvin 1996a).

The first report documents the detail of the equivalency review and identifies actions for consideration that may be necessary to demonstrate nuclear safety equivalency. The second report presents the SNFP's position on each action for consideration identified in the first report and transforms those identified for implementation into a requirements format.

Information included in WHC-SD-SNF-DB-002 (Garvin 1996b) that relates to implementation of the design and construction aspects of 10 CFR 72 was based substantially on Comparison of Nuclear Regulatory Commission and Department of Energy Requirements for Independent Spent Nuclear Fuel Storage Facilities (Scientech 1995), a report written by Scientech, Inc., under DOE contract DE-AC01-92EW50504.

WHC-SD-SNF-DB-003 (Garvin 1996a) contains 29 equivalency items, including the following as item 24:

"Include in the SNF Project Path Forward Integrated Safety Management Plan the requirement to provide for the CSB SAR the information called for in Section 72.24 and Regulatory Guide 3.48 that is not required in DOE 5480.23 and DOE-STD-3009-94 and that is unique to spent nuclear fuel storage."

"Include in the SNF Project Path Forward Integrated Safety Management Plan the requirement to provide for the CVDF and HCS SARs, in consideration of conditioning processes and safety features, relevant information called for in Regulatory Guide 3.26 that is not required in DOE 5480.23 and DOE-STD-3009-94 and that is unique to the conditioning processes. (The review to identify any additional applicable information for the CVD facility or HCS SARs should not occur until the associated processes and safety features are better defined.)" 
HNF-SD-SNF-SP-012 REV 0

\subsection{IMPLEMENTATION}

\subsection{CANISTER STORAgE BUILDING}

Tables 1 and 2 present the information required by NRC Regulatory Guide 3.48 (NRC 1989) and Section 72.24 (10 CFR 72) that is unique to the storage of spent nuclear fuel. The items are 1 isted in Tables 1 and 2 without regard to whether DOE Order 5480.23 or DOE-STD-3009-94 require the inclusion of such information in the FSAR for a nonreactor nuclear facility. In developing these tables, the requirements of Regulatory Guide 3.48 (NRC 1989) were reviewed first as the Regulatory Guide is more detailed in terms of the format and content requirements of the FSAR than is Section 72.24 (10 CFR 72). Items required by Section 72.24 (10 CFR 72), but not by Regulatory Guide 3.48 (NRC 1989), were then identified and included in Table 2.

Table 3 lists the additional items, arranged in DOE-STD-3009-94 format, that must be added to the CSB FSAR. It includes those items identified in Tables 1 and 2 that are not required by DOE Order 5480.23 or by DOE-STD-3009-94 and, therefore, must be added to implement item 24 of WHC-SD-SNF-DB-003. Also included in Table 3 are items that will document implementation of the remaining 28 equivalency items. This latter set is identified in Table 3 by the reference to "Garvin 1996a."

Subsequent to the approval and concurrence of the NRC nuclear safety equivalence documents (Garvin 1996a and 1996b), the NRC issued for comment NUREG-1536, Standard Review Plan for Dry Cask Storage Systems (NRC 1996). This document has been reviewed to gain insight into the content requirements of Regulatory Guide 3.48 (NRC 1989), and appropriate references have been included in the attached tables. However, the draft NUREG-1536 (NRC 1996) was not reviewed to identify additional requirements for the CSB FSAR beyond those of Regulatory Guide 3.48 (NRC 1989) as this is not a requirement for equivalency.

\subsection{COLD VACUUM DRYING FACILITY}

WHC-SD-SNF-DB-003 (Garvin 1996a) states the review of Regulatory Guide 3.26 (NRC 1975) for the CVDF should be based upon an understanding of the associated processes and safety systems. This understanding was obtained from WHC-SD-SNF-SAR-002, Safety Analysis Report for the Cold Vacuum Drying Facility, Phase 1, Supporting Civil/Structural Construction (WHC 1996), through which the following CVDF processes and safety features were identified.

- Heating, ventilating, and air conditioning

Two high-efficiency particulate air filtered fan exhaust systems are provided. The first system exhausts the process bays, change rooms, transfer corridor, and mechanical rooms through high-efficiency particulate air filters and a common stack. Each CVDF bay is served by a dedicated ventilation system (i.e., with its own fan and cleanup train). Stack radionuclide releases are monitored. This system is important to maintaining secondary confinement when the 
cask lid is removed. The second system exhausts the process bay local hoods. This is one system (with redundant fans) that services all of the hoods.

- MCO process systems

Each bay has its own process equipment skids containing all of the MCO processing equipment. The processing equipment is capable of drawing the $K$ Basin water contained in the KCO into a collection system, purging warm dry gas through the $\mathrm{MCO}$, and pulling a vacuum on the MCO. The equipment also includes a hot and chilled water system that establishes and controls the temperature of the MCO during the drying process. Portions of the processing system serve as an extension of the primary containment provided by the $\mathrm{MCO}$.

Other mechanical systems that are distributed to each bay to support the process include a chilled water system for ventilation and process cooling; gases and deionized water; and waste water, floor drain, and radioactive liquid waste collection.

Maintaining the integrity of the process systems is an element in preventing $\mathrm{MCO}$ hydrogen deflagration and detonation. The process system is designed to maintain an inert atmosphere in system components and within the $\mathrm{MCO}$ and to prevent air ingress in order to preclude hydrogen deflagration and detonation. During normal operating process interruptions, or during other events that cause interruption of the process, the system is designed to isolate the $M C O$ and to provide an inert gas purge to the MCO to prevent hydrogen burn events.

- Liquid waste system

Contaminated liquid waste water collected from the MCO during processing is transferred to a collection tank and later pumped to the radioactive liquid waste receiver tank. Design and operation of the liquid waste system provide for criticality control. The criticality prevention strategy is to prevent transfer of fissile material from the MCO by filtering the MCO llquid waste when transferring MCO liquid effluent to the collection tank, then to provide monitoring downstream of the filter or in the collection tank to detect failure of the filter and accumulations in the tank. The collection tank is monitored for fissile content before transfer to the radioactive liquid waste tank. The radioactive liquid waste tank also is monitored periodically for accumulations.

The following elements of the CVDF features listed above could be considered unique to the cold vacuum drying system:

- The function of the process system to drain an MCO, purge and vacuum dry the contents of the MCO, and backfill an MCO with inert gas

- The function of the process system to serve as an extension of the primary confinement provided by the MCO 
- System integrity to preclude hydrogen deflagration and detonation

- Criticality control of the contents of the liquid waste system.

While the CVDF heating, ventilating, and air conditioning systems are very important to controlling the exposure of the workers, public, and environment to radionuclides, their design and operation has no unique considerations for the fuel conditioning process.

The Regulatory Guide 3.26 (NRC 1975) review was focused on the SAR content requirements of the guide as they relate to the four aspects of the CVDF listed above.

Table 4 lists the information identified from this review that should be included in the CVDF SAR. After this table was completed, its content was compared with the content requirements of DOE-STD-3009-94 to identify the information to be included in the SAR that is not required by DOE-STD-3009-94 . The results of this review are provided in Table 5 . This table suggests where the additional material should be included based upon the format requirements of the DOE standard. Also included in Table 5 are items that will document resolution of the remaining equivalency items. This latter set is identified in Table 5 by the reference to "Garvin 1996a."

\subsection{REFERENCES}

10 CFR 72, "Licensing Requirements for the Independent Storage of Spent Nuclear Fuel and High-Level Radioactive Waste, Code of Federal Regulations, as amended.

DOE Order 5480.23, Nuclear Safety Analysis Reports, DOE 5480.23, U.S. Department of Energy, Washington, D.C.

DOE-STD-3009-94, 1994, Preparation Guide for U.S. Department of energy Nonreactor Nuclear Facility Safety Analysis Reports, U.S. Department of Energy, Washington, D.C.

Garvin, L. J., 1996a, Spent Nuclear Fuel Project Path Forward, Additional NRC Requirements, WHC-SD-SNF-DB-003, Rev. 2, Westinghouse Hanford Company, Richland, Washington.

Garvin, L. J., 1996b, Spent Nuclear Fuel Project Path Forward, Nuclear Safety Equivalency to Comparable NRC-Licensed Facilities, WHC-SD-SNF-DB-002, Rev. 2, Westinghouse Hanford Company, Richland, Washington.

Grumbly, T. P., 1995, Concurrence with the K-Basins Spent Nuclear Fuel Program Policy on Nuclear Safety Requirements, (Memorandum EM-36-3.1.6.7 to Manager, U.S. Department of Energy, Richland Operations Office, July 20, 1995), U.S. Department of Energy, Washington D.C. 
NRC, 1975, Standard Format and Content of Safety Analysis Reports for Fuel Reprocessing Plants, Regulatory Guide 3.26, U.S. Nuclear Regulatory Commission, Washington, D.C.

NRC, 1987, Design of an Independent Spent Fuel Storage Installation (Dry Storage), Regulatory Guide 3.60, U.S. Nuclear Regulatory Commission, Washington, D.C.

NRC, 1989, Standard Format and Content for the Safety Analysis Report for an Independent Spent Fuel Storage Installation or Monitored Retrievable Storage Installation (Dry Storage), Regulatory Guide 3.48, Rev. 1, U.S. Nuclear Regulatory Commission, Washington, D.C.

NRC, 1996, Standard Review Plan for Dry Cask Storage Systems, NUREG-1536, draft for comment, U.S. Nuclear Regulatory Commission, Washington, D.C.

Scientech, 1995, Comparison of Nuclear Regulatory Commission and Department of Energy Requirements for Independent Spent Nuclear Fuel Storage

Facilities, Scientech, Incorporated, Rockville, Maryland

WHC, 1996, Safety Analysis Report for the Cold Vacuum Drying Facility, Phase 1, Supporting Civil/Structural Construction, WHC-SD-SNF-SAR-002, Rev. 0 , Westinghouse Hanford Company, Richland, Washington. 
Table 1. Items in Regulatory Guide $3.48^{\circ}$ that are Unique to the Storage of Spent Nuclear Fuel. ( 8 sheets)

\begin{tabular}{|c|c|c|}
\hline $\begin{array}{l}\text { Section and title from } \\
\text { Regulatory guide } 3.48^{8}\end{array}$ & Item unique to spent nuclear fuel storage & $\begin{array}{c}\text { Section and title of location in final } \\
\text { Sefety Analysis Report for the Cenister } \\
\text { Storage Building }\end{array}$ \\
\hline \multicolumn{3}{|c|}{ Chapter 1. "Introduction and General Description of Installation" } \\
\hline $\begin{array}{l}\text { Section 1.1. } \\
\text { "Introduction" }\end{array}$ & Discuss the reeson or need for an ISFSI. & $\begin{array}{l}\text { Section ES.1, "Facility Background and } \\
\text { Mission," and section 2.3, "Facility } \\
\text { Overview" }\end{array}$ \\
\hline $\begin{array}{l}\text { Section 1.2, "General } \\
\text { Description of } \\
\text { Installation" }\end{array}$ & $\begin{array}{l}\text { Briefly discuss the normal capacity of the instal lation; the type, form, } \\
\text { quant ities, and potential sources of the spent fuel to be stored; and the } \\
\text { waste products generated during ISfSI operation. }\end{array}$ & $\begin{array}{l}\text { Section ES.2, "facility Overview," and } \\
\text { Section 2.3," "Facility overview" }\end{array}$ \\
\hline $\begin{array}{l}\text { Section 1.3, "General } \\
\text { Systems Description" }\end{array}$ & $\begin{array}{l}\text { Present a summery description of the storage mode and arrangenent of the } \\
\text { storage structures to be used, including pertinent background information. } \\
\text { Include a brief description of the operating systens; fuel handl ing, decay } \\
\text { heat removal, and other auxiliary systems; ond the site-generated waste } \\
\text { treatment system. }\end{array}$ & section 2.3, "Facillity Overview" \\
\hline \multicolumn{3}{|c|}{ Chapter 2, "Site Characteristics" } \\
\hline $\begin{array}{l}\text { Section } 2.1 .2 \text {, "site } \\
\text { Description" }\end{array}$ & $\begin{array}{l}\text { Clearly delineate the area to be considered as the controlled area } \\
\text { boundary if its boundaries are not the sane as the boundaries of the site. }\end{array}$ & $\begin{array}{l}\text { Section 1.3.1, "Geography" } \\
\text { (This relates to the implenentation of } \\
\text { MRC equivalence for "important to } \\
\text { safety".) }\end{array}$ \\
\hline $\begin{array}{l}\text { Section 2.1.2.1, "Other } \\
\text { Activities Within the site } \\
\text { Boundary" }\end{array}$ & $\begin{array}{l}\text { For any activity conducted within the area of the ISFSI, but not related } \\
\text { to the operation of the facility, identify the activities involved, the } \\
\text { boundaries with in wich the applicant will control such activities, and } \\
\text { any potential interaction of such activities and the operation of the } \\
\text { ISFsI. }\end{array}$ & $\begin{array}{l}\text { Section } 1.7 \text {, wearby Facilities" } \\
\text { (This information is, currently required } \\
\text { by DoE-ST0-3009-94. ) }\end{array}$ \\
\hline $\begin{array}{l}\text { Section } 2.1 .2 .2 \text {, } \\
\text { "Boundaries for } \\
\text { Establishing Effluent } \\
\text { Release Limits" }\end{array}$ & $\begin{array}{l}\text { Discuss the access control that enebles compl iance with the requirements } \\
\text { of } 10 \mathrm{CFR} 72.104 \text {. }\end{array}$ & Section 1.3 .1 , "Geography" \\
\hline $\begin{array}{l}\text { Section } 2.1 .3 \text {, "Population } \\
\text { Distribution and Trends" }\end{array}$ & $\begin{array}{l}\text { Specify the current resident population, as well as projected future } \\
\text { population changes, within each area formed by the concentric circles and } \\
\text { radial lines of a population sector map. }\end{array}$ & $\begin{array}{l}\text { Section 1.3.2, "Demography" } \\
\text { (The equivalency review specifically } \\
\text { recowirended that the design bases for new } \\
\text { swFp path Forward facilities address } \\
\text { probable use of Hanfgrd site lands in the } \\
\text { future [Garvin } 1996 \text { ] } \text { ). }\end{array}$ \\
\hline $\begin{array}{l}\text { Section 2.6.1, Basic } \\
\text { Geologic and Seismic } \\
\text { Information" }\end{array}$ & $\begin{array}{l}\text { Present the methods used tg determine that the site meets the desion } \\
\text { criteria of } 10 \text { CFR } 72.102 \text {. }\end{array}$ & $\begin{array}{l}\text { As muclear safety equivelency is not to } \\
\text { be denonstrated for seismic design, no } \\
\text { additional seismic information need be } \\
\text { provided. }\end{array}$ \\
\hline
\end{tabular}


Table 1. Items in Regulatory Guide $3.48^{\mathrm{a}}$ that are Unique to the Storage of Spent Nuclear Fuel. (8 sheets)

\begin{tabular}{|c|c|c|}
\hline $\begin{array}{l}\text { Section and title from } \\
\text { Regulatory Guide } 3.48\end{array}$ & Iten unique to spent muclear fuel storage & $\begin{array}{l}\text { Section and title of location in Final } \\
\text { Safety Analysis Report for the Cenister } \\
\text { Storege Building }\end{array}$ \\
\hline \multicolumn{3}{|c|}{ Chapter 3, "Principal Design Criteria" } \\
\hline $\begin{array}{l}\text { Section } 3.1 \text {, "Purposes of } \\
\text { Installation" }\end{array}$ & $\begin{array}{l}\text { Describe in generat terms the mode of storage; the installation and its } \\
\text { functions, operation, and storage capacity; and the types of fuel or } \\
\text { high-level waste to be stored. }\end{array}$ & $\begin{array}{l}\text { Section E.2, "Facility Overview," and } \\
\text { Section 2.3, "Facility Overvien" } \\
\text { (This is the sane information as required } \\
\text { by Regulatory Guide } 3.48 \text { for Section } 1.1 \\
\text { with the addition of the discussion of } \\
\text { the mode of storage.) }\end{array}$ \\
\hline $\begin{array}{l}\text { Section } 3.1 .1 \text {, Materials } \\
\text { to be Stored" }\end{array}$ & $\begin{array}{l}\text { Provide detailed deseription of the physical, thermal, and radiological } \\
\text { characteristics of the spent fuel or high-level radioactive wastes to be } \\
\text { stored. Include spent fuel characteristics such as apecific power, } \\
\text { burmp, decay time, and heat generation rates and high-level radioactive } \\
\text { waste characteristics such as cur ie content, waste form, and generation } \\
\text { rates. }\end{array}$ & Section 2.3, "Facility overvien" \\
\hline $\begin{array}{l}\text { Section } 3.1 .2 \text {, "General } \\
\text { Operat ing Functions" }\end{array}$ & $\begin{array}{l}\text { Provide information related to the overall functioning of the installation } \\
\text { as storage operation. Include information on onsite-generated waste } \\
\text { processins. waste packaging and storage arees, transportation, and } \\
\text { utilities. }\end{array}$ & Section 2.5, "Process Description" \\
\hline $\begin{array}{l}\text { Sect ion 3.2.1, "Tornado } \\
\text { and Wind Loedings" }\end{array}$ & $\begin{array}{l}\text { Specify the design paraneters applicable to the design tornado. Describe } \\
\text { the methods used to convert the tornedo and wind losdings into forces on } \\
\text { structures. Show that the failure of any structure not being designed for } \\
\text { tornado loeds will not affect the ability of other sscs important to } \\
\text { safety to perform their intended design functions. Provide the } \\
\text { dimensions, mass, energy, velocity, and other parameters for the } \\
\text { tornado-driven missiles. Analyze the potential effect of such missiles on } \\
\text { sscs important to safety. }\end{array}$ & $\begin{array}{l}\text { To achieve NRC nuclear safety } \\
\text { equivalency, the CSB must be designed to } \\
\text { withstand the ef fects of tornadges and } \\
\text { tornado missiles (Garvin } 1996 \text { ) As DOE } \\
\text { does not require that reactor or } \\
\text { nonreactor nuclear facilities be designed } \\
\text { for tornadoes and tornado missiles, this } \\
\text { information needs to be added to } \\
\text { section } 1.4 .1 \text {, meteorology, to discuss } \\
\text { the parameters that define the design } \\
\text { basis tornedo and tornado missiles, and } \\
\text { to Section } 2.4 \text {, "Facility Structure," in } \\
\text { terms of the design of the csB to } \\
\text { withstand the effects of the tornedo and } \\
\text { tornado missiles as required to protect } \\
\text { safety class i sscs. }\end{array}$ \\
\hline $\begin{array}{l}\text { Section 3.2.3, "Seismic } \\
\text { Design" }\end{array}$ & $\begin{array}{l}\text { Justify the use of response spectral shapes other than those in Regulatory } \\
\text { Guide } 1.60 \text { if they are proposed for design of the storage structures or } \\
\text { other structures that are important to safety. Present the earthquake } \\
\text { time functions or other data fron wich these response spectral shapes } \\
\text { were derived. }\end{array}$ & $\begin{array}{l}\text { As muclear sefety equivalency is not to } \\
\text { be denonstrated for seismic des isn, no } \\
\text { additional seismic information need be } \\
\text { provided. This posifion is documented } \\
\text { in unc-SD-SWF-DB-004. }\end{array}$ \\
\hline
\end{tabular}


Table 1. Items in Regulatory Guide $3.48^{\circ}$ that are Unique to the Storage of Spent Nuclear Fuel. (8 sheets)

\begin{tabular}{|c|c|c|}
\hline $\begin{array}{l}\text { Section and title from } \\
\text { Regulatory Guide } 3.48\end{array}$ & Iten unique to spent muclear fuel storage & $\begin{array}{l}\text { Section and title of location in final } \\
\text { Safety Analysis Report for the Conister } \\
\text { Storage Building }\end{array}$ \\
\hline \multicolumn{3}{|c|}{ Chapter 4, "Installation Design" } \\
\hline $\begin{array}{l}\text { Section 4.1.2.2, } \\
\text { "Control led Aree" }\end{array}$ & Show the controlled area established by the criteria in 10 CFR $72.106 .^{c}$ & Section 1.3.1, "Geogrephy" \\
\hline $\begin{array}{l}\text { Section } 4.3 .2 .2 \text {, "Safety } \\
\text { Consideration and } \\
\text { Control s" }\end{array}$ & $\begin{array}{l}\text { Itemize and discuss the mechanisms and the sequence and timing of events } \\
\text { that will occur in the event of partial loss of normal power and in the } \\
\text { event of a total loss of nomal power. }\end{array}$ & $\begin{array}{l}\text { Section 3.3, "Hazard Analysis" and } \\
\text { Section 3.4, "Accident Analysis" }\end{array}$ \\
\hline $\begin{array}{l}\text { Section } 4.7 \text {, "Spent Fuel } \\
\text { and High-Level Radioactive } \\
\text { Waste Handling Operation } \\
\text { Systems" }\end{array}$ & 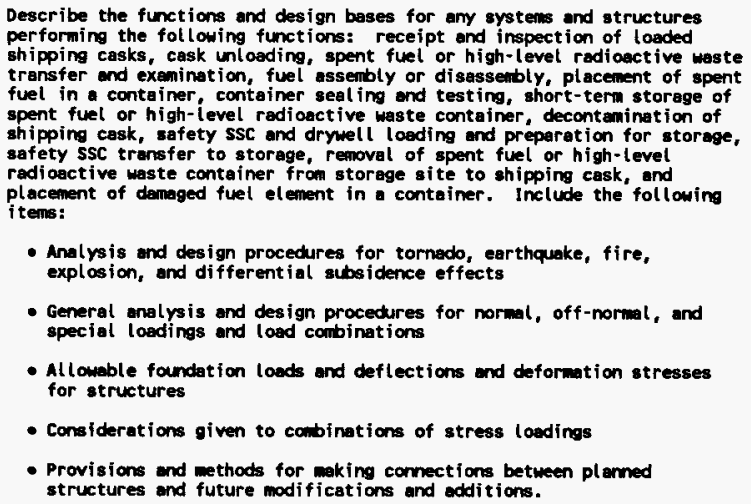 & $\begin{array}{l}\text { Chapter 4.0, "Safety structures, systems, } \\
\text { and Components" }\end{array}$ \\
\hline
\end{tabular}


Table 1. Items in Regulatory Guide $3.48^{*}$ that are Unique to the Storage of Spent Nuclear Fuel. ( 8 sheets)

\begin{tabular}{|c|c|c|}
\hline $\begin{array}{l}\text { Section and title from } \\
\text { Regulatory Guide } 3.48^{6}\end{array}$ & Item unique to spent muclear fuel storege & $\begin{array}{l}\text { Section and title of location in Final } \\
\text { Safety Analysis Report for the Conister } \\
\text { Storage Building }\end{array}$ \\
\hline $\begin{array}{l}\text { Section } 4.7 .3 \text { "Individual } \\
\text { Unit Description" }\end{array}$ & 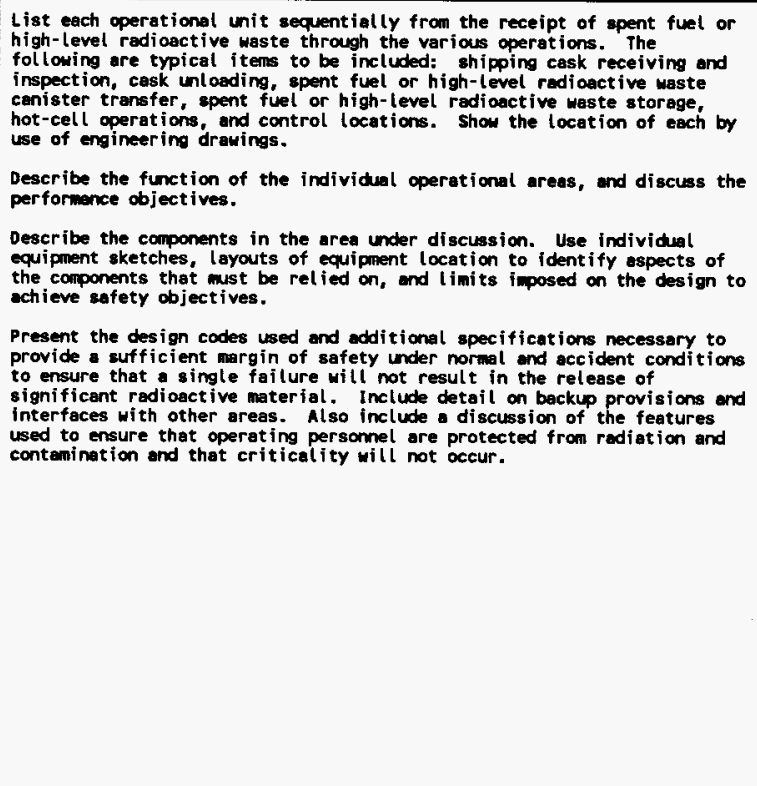 & 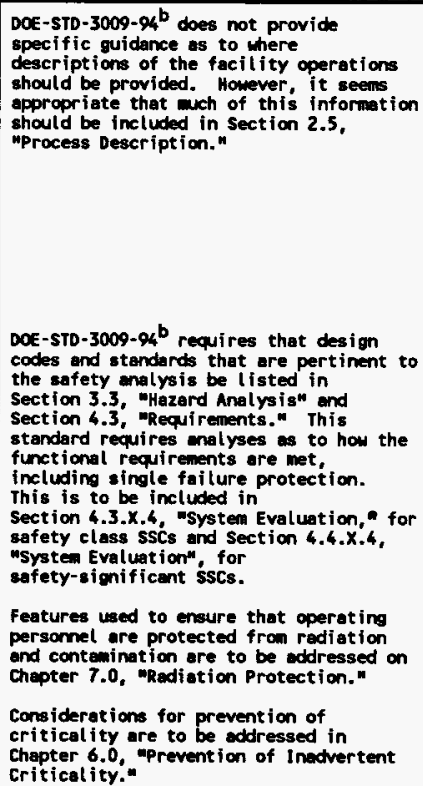 \\
\hline
\end{tabular}


Table 1. Items in Regulatory Guide $3.48^{a}$ that are Unique to the Storage of Spent Nuclear Fuel. (8 sheets)

\begin{tabular}{|c|c|c|}
\hline $\begin{array}{l}\text { Section and title from } \\
\text { Regulatory Guide } 3.48^{8}\end{array}$ & Item unique to spent nuclear fuel storage & $\begin{array}{l}\text { Section and title of location in Final } \\
\text { Safety Analysis Report for the Canister } \\
\text { Storage Building }\end{array}$ \\
\hline \multicolumn{3}{|c|}{ Chepter 5, "Operation Systems" } \\
\hline $\begin{array}{l}\text { Chapter } 5 \text {, "Operation } \\
\text { Systems" }\end{array}$ & $\begin{array}{l}\text { Provide a detailed deseription of all operations, including systems, } \\
\text { equipment, and instrumentation and their operating characteristics. } \\
\text { Identify potentially hazardous operating systems. In the details } \\
\text { presented, designate the provisions ade for operational safety features } \\
\text { to ensure against a hazard, including, but not be l imi ted to, backup or } \\
\text { standby features and any systens necessary for curtail ing operations under } \\
\text { normal and off-normal conditions, for maintaining the installation in a } \\
\text { safe condition, and for secondary conf inenent. }\end{array}$ & $\begin{array}{l}\text { DoE-STD-3009-94b does not provide } \\
\text { specific guidence as to where } \\
\text { descriptions of facil ity operations } \\
\text { should be provided. However, it seens } \\
\text { eppropriate that much of this information } \\
\text { should be included in Section } 2.5 \text {, } \\
\text { "Process Description." }\end{array}$ \\
\hline $\begin{array}{l}\text { Section } 5.1 .1 \text {, "Marrative } \\
\text { Description" }\end{array}$ & $\begin{array}{l}\text { Describe the proposed spent fuel and high-level radioactive waste handling } \\
\text { and passive storage operations and relate then to the equipment and } \\
\text { associated controls. Include pertinent ancillary activities (i.e.. } \\
\text { preparation of reactants, offges handl ing, volume reduction of wastes, and } \\
\text { decontamination). Identify the interfaces between systems, and discuss } \\
\text { the safety aspects of the interfaces. }\end{array}$ & $\begin{array}{l}\text { DOE-STD-3009-94b does not provide } \\
\text { specific guidance os to were } \\
\text { descriptions of facil ity operations } \\
\text { should be provided. However, it seems } \\
\text { appropriate that mach of this information } \\
\text { should be included in Section } 2.5 \text {. } \\
\text { uprocess Description." }\end{array}$ \\
\hline $\begin{array}{l}\text { Section } 5.1 .3 .1, \\
\text { "Criticality Prevention" }\end{array}$ & $\begin{array}{l}\text { Provide a sumary description of the principal design features, } \\
\text { procedures, and special techniques used to preclude criticality in all } \\
\text { portions of the installation. }\end{array}$ & $\begin{array}{l}\text { DOE-STO-3009-94b requires that } \\
\text { considerations for prevention of } \\
\text { criticality be eddressed in Chapter } 6.0 \text {, } \\
\text { wrevention of Inadvertent Criticality." }\end{array}$ \\
\hline $\begin{array}{l}\text { Section } 5.2 .1 .1, \\
\text { "Functional Description" }\end{array}$ & $\begin{array}{l}\text { Present a flow diagram and functional description of the spent fuel or } \\
\text { high-level radioactive waste receiving, storage, and retrieval systens, } \\
\text { including provisions for handling defective fuel assembl ies or damaged } \\
\text { high-level radioactive waste containers. Include drawings or references } \\
\text { to drowings os needed. }\end{array}$ & 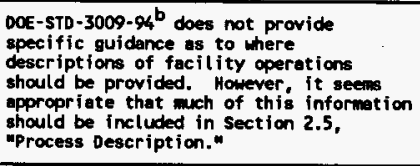 \\
\hline $\begin{array}{l}\text { Section } 5.2 .2 \text {, "Spent Fuel } \\
\text { or High-Level Radioactive } \\
\text { Haste Storage" }\end{array}$ & $\begin{array}{l}\text { Describe the operations used for transfer of spent fuel assembl ies or } \\
\text { high-level waste containers to the storage positions, the storage } \\
\text { surveillence program, end the operations used for renoval from the storage } \\
\text { position. Describe all features, systems, and special techniques included } \\
\text { in the system that provide for the safety of the operation under both } \\
\text { normal and off-normal conditions. Include the limits selected for a } \\
\text { commitment to action. }\end{array}$ & $\begin{array}{l}\text { ooE-STD-3009-94b does not provide } \\
\text { specific guidance as to where } \\
\text { descriptions of facil ity operations } \\
\text { should be provided. However. it seens } \\
\text { appropriate that much of this information } \\
\text { should be included in Section 2.5, } \\
\text { mprocess Description." }\end{array}$ \\
\hline
\end{tabular}


Table 1. Items in Regulatory Guide $3.48^{\circ}$ that are Unique to the Storage of Spent Nuclear Fuel. ( 8 sheets)

\begin{tabular}{|l|l|l|}
\hline $\begin{array}{l}\text { Section and title from } \\
\text { Regulatory Guide } 3.48^{8}\end{array}$ & I ten unique to spent nuclear fuel storage & $\begin{array}{c}\text { Section and title of location in final } \\
\text { Safety Analysis Report for the Canister } \\
\text { Storage Bui lding }\end{array}$ \\
\hline
\end{tabular}

Chapter 6, "Site-Generated Maste Conf inement and Managenent"

This section addresses waste that is generated as a result of the ISfS1 operation. It does not refer to the high-level radioective wastes that may be stored in the facility.

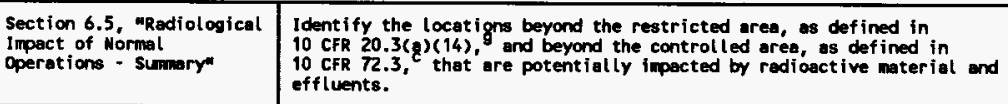

Chapter 7, "Radiation Protection*

This chapter requires detailed discussion of the inplementation of Regulatory Guide 8.8. ${ }^{\text {h }}$ facilities, the information required in Regulatory Guide $3.48^{a}$ regarding implementation of the desion aspects of Regulatory Guide $8.8^{\text {h }}$ should be included in the CSB FSAR.

This chapter is to provide a discussion of anolyses for off-normal operations and accidents. Site characteristics that have a bearing on the safety andises are also to be discussed.

For the analyses of off-normal operatioss, Regulatory Guide $3.48^{\circ}$ refers to events of the first and second type os discussed in ANSI/ANS-57.9-1992 (ANSI/ANS-57.9-1992 Uses the terminology udosign Event 1, II, III and IV"). Events of the first type are defined in ANSI/ANS-57.9-1992, Section 2, "Definitions," as events that are expected to occur regularly or frequently in the course of normal operation of the ISFSI. Events of the second type are defined as those not occurring regularly, but expected to occur with moderate frequency or on the order of once during a calendar year of ISFSI operation. In practice, utilities applying for licenses under 10 cFR 72 , have not addressed events of the first type in Chapter 8 of their safety analysis reports as off-normal conditions or accidents. such events have no consequence af they are within the operating design requirements for the facility. For example, implenentation of this aspect of ANSI/ANS-57.9-1992 would require analyses of normal activities related to transportation, epent fuel transfer, hendling of radioactive waste, fuel preparation, and placement of the spent fuel in the storage locations. These would be addressed without any postulated equipnent failure or operator error. Some safety analysis reports have simply provided a list of the design criteria for normal operating conditions. For the CSB FSAR, written to the format of DOE-STD-3009-94, the confi mation that SSCs are designed for the eppropriate loodings can be discussed in Chapter 4.0, "Safety Structures, Systens, and Components." This suggestion is supported by MUREG-1536, wich states that Chapter 11, "Accident Analysis," should address off-normal and accident conditions and that loading for normal operation should be addressed in chapter 3, "structural Evaluation."

For the enalyses of eccidents, Regulatory Guide $3.48^{\circ}$ refers to events that would potentially result in a dose of 25 mrei or greater beyond the controlled area and to events of the third and fourth type as discussed in ANSI/ANS-57.9-1992 (ANSI/ANS-57.9-1992 uses the terminology Design Event I, II, III and IVW). Events of the third type are defined as that set of infrequent events that could be reesonghy expected to occur during the tifetime of the ISFSI. Events of the fourth type are postulated because their consequences may result in the maxime potential impact on the imediate environs. Their consideration establishes a conservative design besis for certain systems that are important to conf inement. 
Table 1. Items in Regulatory Guide $3.48^{\mathrm{a}}$ that are Unique to the Storage of Spent Nuclear Fuel. (8 sheets)

\begin{tabular}{|c|c|c|}
\hline $\begin{array}{l}\text { Section and title from } \\
\text { Regulatory cuide } 3.48^{\circ}\end{array}$ & Item unique to spent muclear fuel storage & $\begin{array}{c}\text { Section and title of location in Final } \\
\text { Safety Analysis Report for the Canister } \\
\text { Storage Building }\end{array}$ \\
\hline
\end{tabular}

Chapter 8, maccident Analyses"

(continued)

For the CSB FSAR, the requirement of DOE-STD-3009-94 Chapter 3.0, to perform a hazards analysis that cons iders the complete spectrun of accidents that may result from facility operations will implentent the requi rentent of Regulatory Guide 3.48 to consider events of the second, third, and fourth type, and events hose offsite dose could equal or exceed 25 mren. Safety onalysis reports written to meet the requirements of 10 CFR $72 \mathrm{c}$ provide analyses for the failure of the spent nuclear fuel containment vessel even if no credible scenarios were identified that could result in a breach of the vessel (MUREG-1536, Segtion $v$ ). The jodionucl ide releases are limited to fission product gases. The NRC assumes release of $30 x$ of the krypton and 10\% of the I (MUREG-1536, Chapter 7.0, Section V.2.). The reported of fsite doses are typicall $y_{\text {bless }}$ then 2 rem. For the CSB FSAR, the need to consider beyond design bes is events will be addressed by the requireenent
of DOE-STD-3009-94, Section 3.4.3, meeyond Design Bas is Accidents, w that accidents beyond the design bes is be evaluated to provide a perspective for the residual risk associated with the operation of the facility. Thus, implementat jon of DOE-5TD-3009-94 will result in the selection of off-normal events and accidents similar to those requi red by Regulatory Guide 3.48 . However, events designated as an AUS1/AKS-57.9-1992 Design Event 1 that have no consequences to the facility worker, coll located worker, public, or envirorment will be addressed by confirmation that the operational design loadings for the CSB will not be exceeded during nornal facility operation.

Regulatory Guide $3.48^{\circ}$ does require the presentation of information regarding the analysis of off-normal conditions and accidents that is not specifically stated in DOE-STD-3009-94, "Section 3.4, "Accident Analysis." However, these differences do not relate to spent muclear fuel storege.

Section 8.2 of Regulatory Guide $3.48^{\circ}$ requires that accident analyses address situations herein direct radiation or redioactive materials may be released in such quantity as to endanger personnel within the control led area. The Regulatory Guide. hovever, does not require that

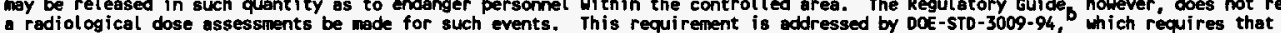
Section 3.3.2.3.3 of the SAR sumberize the major features protecting workers from hazards of facility operation. It should be noted that Section 3.3.2.3.3 of the SAR sLmarize the major features protecting workers from hazards of facility operation. It should be noted that design basis accidents for any individual located at or beyond the nearest control led area boundary (not to exceed 5 rem).

Chapter 9, "Conduct of Operations"

This chapter is to provide infornation on the applicant's organizational structure, preoperational testing and facility operation, training programs, normal operations, energency plaming, decomissioning plan, physical security, and safeguards and contingency plans. Sone of the information to be provided is unique to the storage of spent nuclear fuel, such as record keeping (9.4.2), emergency planning (9.5), ond decomissioning (9.6). However, as this information is not unique to spent nuclear fuel storage, it does not need to be included in the csB FSAR. Also, hile, the MRC requirements for physical security and safeguards could involve design and construction issues, the MRC muclear equivalency reviewk did not identify any such issues from either 10 CFR 72 or 10 CFR 73 .

Chepter 10, "operating Controls and Limits"

This chapter is to provide information on the development of licensing conditions and technical specifications. As none of the required information is unique to spent nuclear fuel storage, no additional information is required in the CSB FSAR. 
Table 1. Items in Regulatory Guide $3.48^{\circ}$ that are Unique to the Storage of Spent Nuclear Fuel. (8 sheets)

\begin{tabular}{|l|l|l|}
\hline $\begin{array}{l}\text { Section and title from } \\
\text { Regulatory Guide } 3.48\end{array}$ & Item unique to spent nuclear fuel storage & $\begin{array}{c}\text { Sect ion and title of location in Final } \\
\text { Safety Analysia Report for the Canister } \\
\text { Storage Building }\end{array}$ \\
\hline
\end{tabular}

Chepter 11, mulitity Assurance"

This chapter is to include a discussion of the appl icant's quality assurance program to ensure that it meets the requirements of $10 \mathrm{CFR} 72$, Subpert ${ }^{6}$. The NRC nuclear safety equivalency revipw establ ished that the combination of 10 CFR $830.120^{\circ}$ and the WHC ausl ity Assurance Manual, "aR 1.0 are equivalent to MRC requirenents. Therefore, there is no need for the cSB FSAR to address the epecific requirements of 10 CFR 72 , Subpart 6 .

MRC, 1989, Standard Format and Content for the Safety Analysis Report for an Independent Spent Fuel storage Installation or Monitored Retrievable Storage Installation (Dry Storage), Regulatory Guide 3.48, Rev. 1, U.S. Nuclear Regulotory Comission, Washington, D.C.

DOE-STO-3009-94, 1994, Preparation Guide for U.S. Department of Eneró Monreactor Muclear Facil ity Safety Analys is Reports, U.S. Department

of Energy, Washington, D.C.

Fó CFR 72, "Licensing Requirements for the Independent Storage of Spent Wuclear Fuel and High-Level Radioective Waste," code of Federal Requlations, as amended.

Garvin, L. J, 1996, Spent Vuclear Fuel Project Path Forward, Nuclear Safety Ecuivalency to comparable wRC-Licensed facilities,

UHC-SO-SNF-DB-003, Rev. 2, Westinghouse Hanford Company, Richland, Washington.

MRC, 1973, Design Response Spectre for Seismic Design of Nuclear Power Plants, Reoulatory Guide 1.60, Rev. 1, U.S. Muclear Regulatory Commissjon, Washington, D.C.

Garvin, L. J., 1996, Spent Muclear Fuel Project Seisaic pesign Criteria, HRC Equivalency Evaluation Report, WHC-sD-swF-DB-004, Rev. 2,

Uest inghouse Hanford Company, Richland, Hashington.

910 CFR 20, "Standards for Protection Against Radiation," Code of Federal Requlations, as anended.

Achievable, Regulatory Guide 8.8, U.S. Nuctear Regulatory Commission, Washington, D.C.

ANSI/ANS, 1992, Design Criteria for en Independent Spent Fuel Storage Instal lation (Dry Iype), ANSI/ANS-57.9-1992, Amerícen Nuclear

MRC, 1996, Standard Review Plan for Pry Cask Storage Systems, NUREG-1536, draft for comment, U.S. Muclear Regulatory Conmission, Wash ington, D.C.

Rev. 2, Hestinghouse Henford Company, Richland, Washington.

10 CFR 73, "Physical Protection of Plants and Materials," Code of federal Regulations, as amended.

$m_{10}$ CFR 830.120, "Qual ity Assurance," Code of Federal Regulations, as anended.

"WHC-CI-4-2, Qúl ity Assurance Manual, Flwor Daniel Henford, Incorporated, Richlend, Weshington.

CSB = Cenister Storage Building.

DOE = U.S. Depertment of Energy.

FSAR = final safety analysis report.

MRC = U.S. Nuclear Regulatory Comission.

ISFSI = independent spent fuel storage instal lation.

SNFP = Spent Muclear Fuel Project.

SSC = structure, system, and component. 
Table 2. Items in Title 10, Code of Federal Regulations, Section 72.24," that are Unique to the Storage of Spent Nuclear Fuel. (2 sheets)

\begin{tabular}{|c|c|c|}
\hline $\begin{array}{l}\text { Section of Iitle } 10, \text { Code } \\
\text { of federal Regulations, } \\
\text { Part } 72^{*}\end{array}$ & Item unique to spent nuclear fuel storage & $\begin{array}{l}\text { Section and title of locetion in Final } \\
\text { Sefety Analysis Report for the Canister } \\
\text { Storage Building }\end{array}$ \\
\hline $72.24(a)$ & $\begin{array}{l}\text { 1f the proposed ISFSI is to be located on the site of a mactear power } \\
\text { plant or other licensed facility, evaluate potential interactions. }\end{array}$ & $\begin{array}{l}\text { Section 1.7, "Wearby Facilities." This } \\
\text { information is cyrrently requi red by } \\
\text { DOE-STD-3009-94. The presence of the } \\
\text { HCS Amex will be oddressed in } \\
\text { Section 2.5. "Process Systens," and } \\
\text { Chapter 3.0, "Hazard and Accident } \\
\text { Analyses," When the HCS Amex is added to } \\
\text { the CSB SAR. }\end{array}$ \\
\hline $72.24(b)$ & $\begin{array}{l}\text { Provide description and discussion of the ISFSI structures with special } \\
\text { attention to design and operating characteristics, unusual or novel design } \\
\text { features, ond principal safety considerations. }\end{array}$ & $\begin{array}{l}\text { Chapter 4.0, "Safety Structures, Systems, } \\
\text { and Components." Al so see response } \\
\text { provided inc Table } 1 \text { for Regulatory } \\
\text { Guide 3.48, Section } 4.7 \text {. }\end{array}$ \\
\hline $72.24(c)(1)$ & $\begin{array}{l}\text { Address the design eriteria for the ISFst or MRS pursuent to subpert } F \text { of } \\
10 \text { CFR } 72 \text {, with identification and justification for amy additions to or } \\
\text { depertures from the general design criteria. }\end{array}$ & Chapter 2.0, "Facility Description" \\
\hline $72.24(e)$ & $\begin{array}{l}\text { Deseribe the means for controlling and ligiting occupational radiation } \\
\text { exposures within the limits of } 10 \text { CFR } 20 \text {. }\end{array}$ & $\begin{array}{l}\text { Chapter 7.0, "Radiation Pgotection." The } \\
\text { extent to wich } 10 \text { CFR } 20^{d} \text { is to be } \\
\text { implemented for the CSB is def ined in } \\
\text { WHC-SD-SWF-DB-003. }\end{array}$ \\
\hline $72.24(i)$ & $\begin{array}{l}\text { Address SSCs important to safety those functional odequacy or reliability } \\
\text { have not been demonstrated. }\end{array}$ & $\begin{array}{l}\text { Chapter 4.0, "Safety structures, Systems, } \\
\text { and Components." }\end{array}$ \\
\hline $72.24(1)(1)$ & $\begin{array}{l}\text { Provide an estimate of the quantity of each of the principal radionucl ides } \\
\text { expected to be released annully to the environment in liquid or gaseous } \\
\text { effluents produced during normal operations. }\end{array}$ & 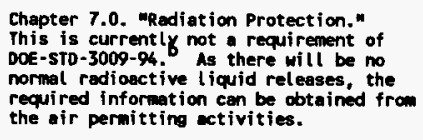 \\
\hline $72.24(m)$ & $\begin{array}{l}\text { Perform calculations of individual dose equivalent or committed dose } \\
\text { equivalent for direct exposure, inhalation, and ingestion occurring as a } \\
\text { result of the postulated design besis event. }\end{array}$ & $\begin{array}{l}\text { Chapter 8.0. "Hazard and Accident } \\
\text { Analyses." }\end{array}$ \\
\hline
\end{tabular}


Table 2. Items in Title 10, Code of Federal Regulations, Section 72.24," that are Unique to the Storage of Spent Nuclear Fuel. (2 sheets)

\begin{tabular}{|c|c|c|}
\hline $\begin{array}{l}\text { Section of Title } 10, \text { Code } \\
\text { of Federal Regullations. } \\
\text { Part } 72^{0}\end{array}$ & Iten unique to apent nucleer fuel storage & $\begin{array}{l}\text { Section and title of location in Final } \\
\text { Safety Analysis Report for the Cenister } \\
\text { Storage Building }\end{array}$ \\
\hline $72.24(n)$ & $\begin{array}{l}\text { Provide a description of the quality essurance program that satisfies the } \\
\text { requirements of Subpert } 6 . \text {. The description must identify ssCs important } \\
\text { to safety. }\end{array}$ & 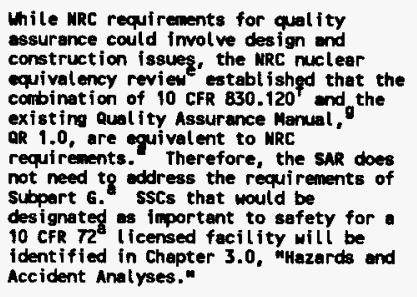 \\
\hline $72.24(0)$ & $\begin{array}{l}\text { Describe the detailed security measures for physical protection, including } \\
\text { design features and the plans required by subpart } \mathrm{H} \text {. }\end{array}$ & $\begin{array}{l}\text { While MRC requirements for physical } \\
\text { security and safeguards could involve } \\
\text { design and construct ion issues, the MRC } \\
\text { nuclear equivalency review did not } \\
\text { ident ify ony such issues from } 10 \text { CFR } 72 \text {. } \\
\text { Therefore the SAR does not need to } \\
\text { oddress the requirenents of subpart } H \text {. }\end{array}$ \\
\hline
\end{tabular}

"10 CFR 72, "Licensing Requirements for the Independent storage of Spent Huclear Fuel and High-Level Radioactive Waste," Code of Federal Requlations, as amended.

DOE-STD-3009-94, 1994, Preparation Guide for U.S. Department of Energy Monreactor Nuclear Safety Analygis Reports, U.5. Department of Energy, Washington, D.C.

NRC, 1989, Standard Format and Content for the Safety Analysis Report for an Independent Spent Fuel Storage Installation or Monitored Retrievable Storage Installation (Dry Storage), Regulatory Guide 3.48, Rev. I, U.s, Muclear Regulatory Combission, Mashington, D.C.

10 CFR 20, "Standards for Protection Against Radiation," Code of Federal Regulations, os anended.

uHC-SD-Garvin, L. J., 199\%, Spent Huclear Fuel Project Path Fomard, Iluclear Safety Equivalency to Comparable MRC-Licensed Focilities.

NF-DB-002, Rev. 2, Hestinghouse Hanford Company, Richland, Washington

10 CFR 830.120, "Qúlity Assurance Requirements," Code of Federal Regulations, as anded.

WHC-CH-4-2, Quility Assurance Manual, Fluor Daniel Henford, Incorporated, Richland, Weshington.

CSB = Cenister Storege Building.

HCS = Hot Conditioning System.

ISFSI = independent spent fuel torage instal lation.

MRS = moni tored retrievable storage.

MRC $=$ U.S. Muclear Regulatory Comission.

SAR = safety onatysis report.

SSC = structure, system, and component. 
Table 3. Information to be Added to the Final Safety Analysis Report for the Canister Storage Building that is not Required by DOE Order $5480.23^{\mathrm{a}}$ or by DOE-STD-3009-94 Needed to Implement Nuclear Safety Equivalency. (8 sheets)

\begin{tabular}{|c|c|c|}
\hline $\begin{array}{l}\text { Section and title from } \\
\text { DOE-STD-3009-94. }\end{array}$ & Material to be added (source) & Cownent \\
\hline \multicolumn{3}{|l|}{ "Execut ive summary" } \\
\hline $\begin{array}{l}\text { Section ES.1, "Fecility } \\
\text { Background and Mission" }\end{array}$ & Discuss the need for the Csi (Regulatory Guide $3.48,{ }^{c}$ section 1.1). & \\
\hline $\begin{array}{l}\text { Section ES.2, "Facility } \\
\text { Overview" }\end{array}$ & $\begin{array}{l}\text { Briefty discuss the mode of otorage; its functions and operation; the } \\
\text { normal capacity of the CSB; the types, forms, quantities, and potential } \\
\text { sources of the spent fuel and high-level waste to be stored; and the } \\
\text { waste products generated during CSB operation (Regulatory ouide } 3.48 \text {, } \\
\text { Sections } 1.2 \text { and } 3.1 \text { ). }\end{array}$ & $\begin{array}{l}\text { It is not expected that any waste } \\
\text { products will be generated. }\end{array}$ \\
\hline $\begin{array}{l}\text { Section ES.7, "Safety Analysis } \\
\text { Report Organization" }\end{array}$ & $\begin{array}{l}\text { Discuss the marner in which the FSAR has been augmented to add that } \\
\text { information from Regulatory Guide } 3.48 \text { and } 10 \text { CFR } 72.24 \text { that is } \\
\text { unique to the storage of spent nuclear fuel (Garvin 1996). }\end{array}$ & \\
\hline \multicolumn{3}{|c|}{ Chapter 1.0, "Site Charecteristics" } \\
\hline Section 1.3.1, "Geography" & 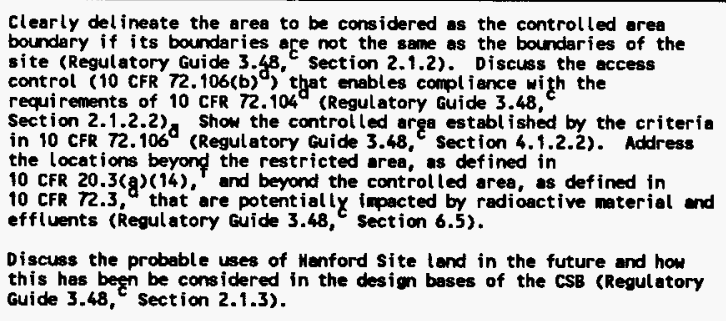 & $\begin{array}{l}\text { These relate to the implementation } \\
\text { of HRC equivalence for "important to } \\
\text { safety." }\end{array}$ \\
\hline Section 1.4.1, Mileteorology" & 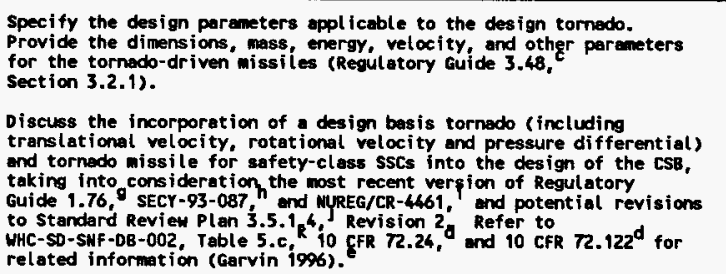 & 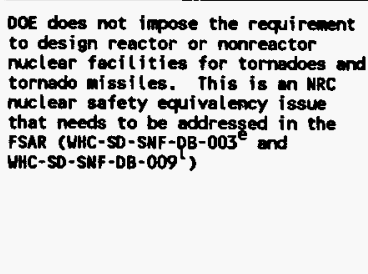 \\
\hline
\end{tabular}


Table 3. Information to be Added to the Final Safety Analysis Report for the Canister Storage Building that is not Required by DOE Order $5480.23^{\circ}$ or by DOE-STD-3009-94 but is Needed to Implement Nuclear Safety Equivalency. (8 sheets)

\begin{tabular}{|c|c|c|}
\hline $\begin{array}{l}\text { Section and title from } \\
\text { DOE-STD-3009-94 }\end{array}$ & Material to be edded (source) & Cominent \\
\hline Section 1.7, "Nearby Facilities" & $\begin{array}{l}\text { Identify the locetions beyond the restricted area, ss defined in } \\
10 \mathrm{CFR} 20.3(\mathrm{~g})(14) \text {, and beyond the controlled area, as defined in } \\
10 \mathrm{CFR} 72.3 \text {, that are potentially inpacted by radionctive material and } \\
\text { effluents (Regulatory Guide } 3.48 \text {, section } 6.5 \text { ). }\end{array}$ & \\
\hline $\begin{array}{l}\text { Chepter 2.0, "Focility } \\
\text { Description }\end{array}$ & $\begin{array}{l}\text { Address the compliance of the design gnd construction of the cSB to the } \\
\text { general design criteria of } 10 \text { CFR } 72 \text {, subpart } F \text {. Include } \\
\text { identification and justification, for ary additions or departures fram } \\
\text { the criteria }(10 \text { CFR } 72.24(c)(1) \%) \text {. } \\
\text { Discuss the margins of safety during normal operations and expected } \\
\text { operational occurregces during the life of the CSB } \\
\text { (10 CFR } 72.24(d)(1) \text { ). }\end{array}$ & \\
\hline $\begin{array}{l}\text { Section 2.4, "Facility } \\
\text { Structure" }\end{array}$ & 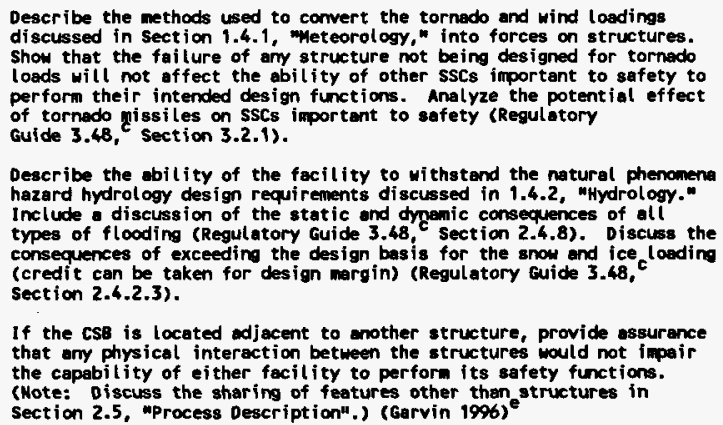 & $\begin{array}{l}\text { See the conment provided for } \\
\text { Section } 1.4 .1 \text {, "weteorology," } \\
\text { regarding the reason for adding } \\
\text { discussions of tornedoes and tornado } \\
\text { missiles. }\end{array}$ \\
\hline
\end{tabular}


Table 3. Information to be Added to the Final Safety Analysis Report for the Canister Storage Building that is not Required by DOE Order $5480.23^{\mathrm{a}}$ or by DOE-STD-3009-94 but is Needed to Implement Nuclear Safety Equivalency. (8 sheets)

\begin{tabular}{|c|c|c|}
\hline $\begin{array}{l}\text { Section and title from } \\
\text { DOE-STD-3009-94 }\end{array}$ & Material to be added (source) & Comment \\
\hline $\begin{array}{l}\text { Section 2.5, "Process } \\
\text { Description" }\end{array}$ & 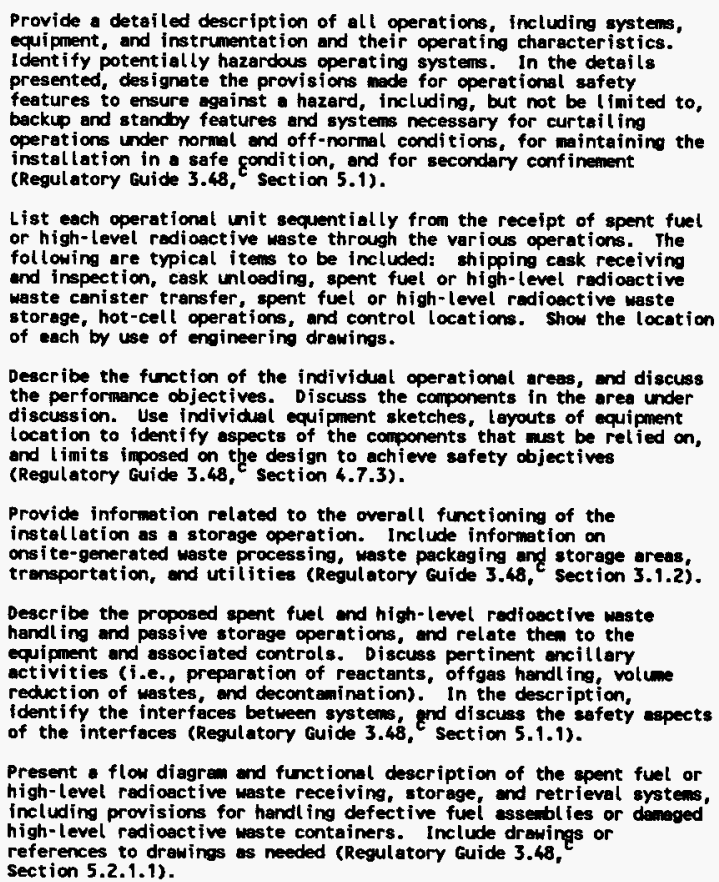 & $\begin{array}{l}\text { Mote that these paragraphs were } \\
\text { taken from several locations within } \\
\text { Regulatory Guide } 3.48 \text { and, as such, } \\
\text { some of the material is repetitive. } \\
\text { The requirenent is to provide the } \\
\text { information requested, but not } \\
\text { necessarily in the order presented } \\
\text { here. } \\
\text { It is important that all operations } \\
\text { and processes that are identified as } \\
\text { inportant to safety be oddressed. }\end{array}$ \\
\hline
\end{tabular}


Table 3. Information to be Added to the Final Safety Analysis Report for the Canister Storage Building

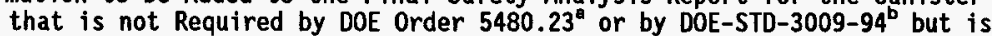

Needed to Implement Nuclear Safety Equivalency. (8 sheets)

\begin{tabular}{|c|c|c|}
\hline $\begin{array}{l}\text { Section and title from } \\
\text { DOE-STD-3009-94 }\end{array}$ & Material to be added (source) & Conivent \\
\hline $\begin{array}{l}\text { Section } 2.5 \text {, "Process } \\
\text { Description" } \\
\text { (cont inved) }\end{array}$ & 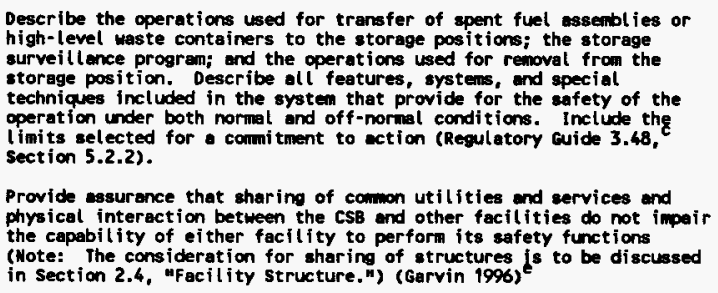 & \\
\hline $\begin{array}{l}\text { Chapter 3.0, "Hazards and } \\
\text { Accident Analyses" }\end{array}$ & $\begin{array}{l}\text { Evaluate those nearby activities identified in Section } 1.6 \text {, "External } \\
\text { Human-Generated Threats," that may represent. threet to the facility. }\end{array}$ & \\
\hline $\begin{array}{l}\text { Chapter 4.0, "Safety Structures, } \\
\text { Systens, and Components" }\end{array}$ & 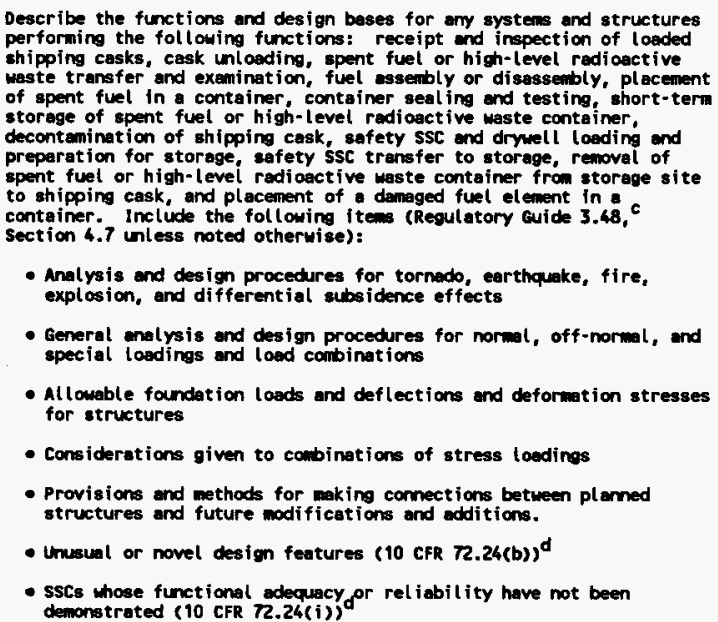 & $\begin{array}{l}\text { Chapter } 2.0 \text {, "Facility Description," } \\
\text { may be a more appropriate location } \\
\text { for this information. }\end{array}$ \\
\hline
\end{tabular}


Table 3. Information to be Added to the Final Safety Analysis Report for the Canister Storage Building

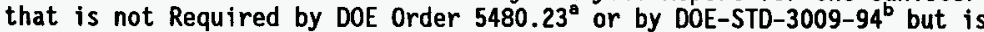
Needed to Implement Nuclear Safety Equivalency. (8 sheets)

\begin{tabular}{|c|c|c|}
\hline $\begin{array}{l}\text { Section and title from } \\
\text { DOE-STD-3009-94 }\end{array}$ & Material to be added (source) & comment \\
\hline $\begin{array}{l}\text { Section 4.3, "Safety-Class } \\
\text { systems, structures, and } \\
\text { Components" }\end{array}$ & 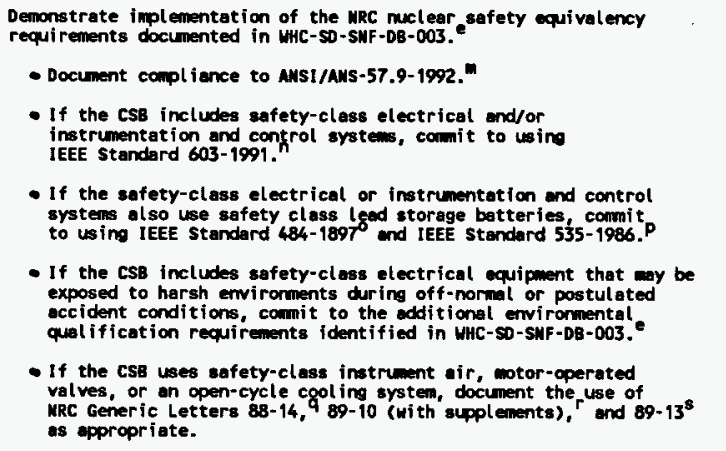 & \\
\hline
\end{tabular}


Table 3. Information to be Added to the Final Safety Analysis Report for the Canister Storage Building that is not Required by DOE Order $5480.23^{\mathrm{a}}$ or by DOE-STD-3009-94 but is Needed to Implement Nuclear Safety Equivalency. (8 sheets)

\begin{tabular}{|c|c|c|}
\hline $\begin{array}{l}\text { Section and title from } \\
\text { DOE-STD-3009-94 }\end{array}$ & Material to be edded (source) & Comment \\
\hline $\begin{array}{l}\text { Chapter } 6.0 . \text { "Prevention of } \\
\text { Inedvertent criticality" }\end{array}$ & 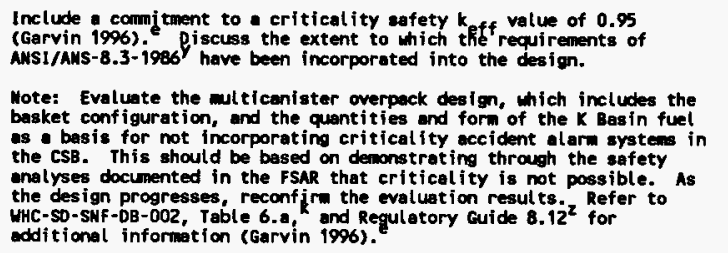 & \\
\hline $\begin{array}{l}\text { Chapter } 7.0, \text { "Radiation } \\
\text { Protection" }\end{array}$ & 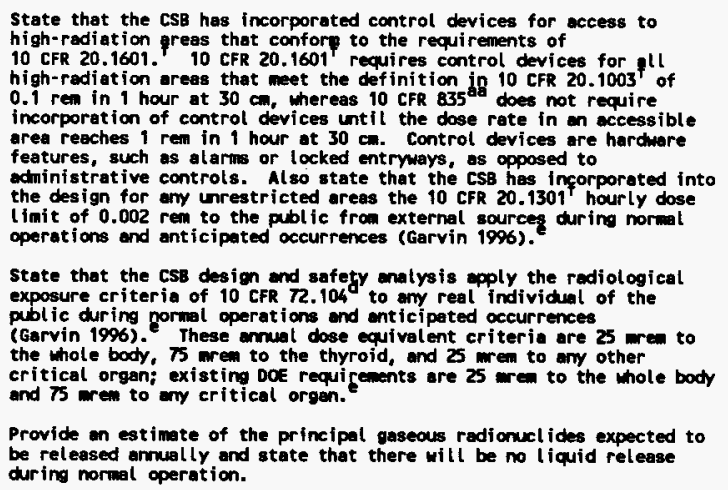 & $\begin{array}{l}\text { This also responds to } \\
10 \mathrm{CFR} 72.24(e) \text { of Toble } 2 \text {. }\end{array}$ \\
\hline $\begin{array}{l}\text { Section 7.4, "ALARA Policy and } \\
\text { Progrem" }\end{array}$ & $\begin{array}{l}\text { Show that the design requirements of Regutatory quide } 8.8^{\text {bb }} \text { hove been } \\
\text { inplemented. Provide the information required by Regulatory } \\
\text { Guide } 3.48 \text { for FSAR section } 7.3 \text {, "Radiation Protection Design } \\
\text { Features, to show that the design requirements of Regulatory } \\
\text { Guide } 8.8 \text { have been satisfied (Regulatory cuide } 3.48 \text {, section 7.3). }\end{array}$ & \\
\hline $\begin{array}{l}\text { Section 7.7, "Radiological } \\
\text { Monitoring" }\end{array}$ & $\begin{array}{l}\text { Document that the provisiops for radiological monitoring will meet the } \\
\text { requirements of } 10 \text { CFR 20, } 10 \text { CFR } 70.59 \text {, and } 10 \text { CFR } 835 \text { st } \\
\text { (Garvin 1996). }\end{array}$ & \\
\hline
\end{tabular}


Table 3. Information to be Added to the Final Safety Analysis Report for the Canister Storage Building that is not Required by DOE Order $5480.23^{a}$ or by DOE-STD-3009-94 $4^{b}$ but is Needed to Implement Nuclear Safety Equivalency. (8 sheets)

\begin{tabular}{|c|c|c|}
\hline $\begin{array}{l}\text { Section and title from } \\
\text { DOE-STD-3009-946 }\end{array}$ & Material to be added (source) & Comment \\
\hline $\begin{array}{l}\text { Chapter 8.0, "Hazards and } \\
\text { Accident Anal ys is" }\end{array}$ & Address the ingestion pathway. & \\
\hline Section 11.4, "fire Protection" & 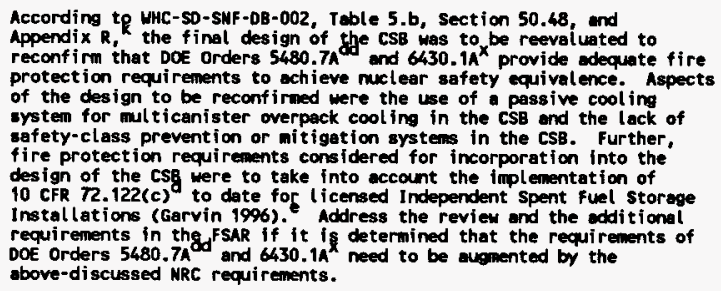 & \\
\hline Chapter 13.0, "Humen factors" & 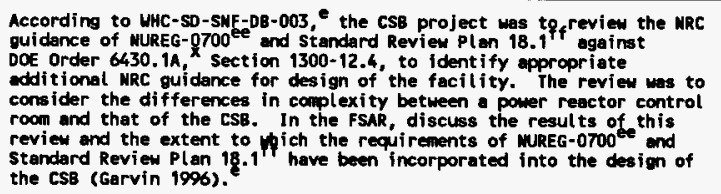 & \\
\hline
\end{tabular}

DOE Order 5480.23, 1992, MUclear Safety Analysis Reports, DOE 5480.23, U.S. Department of Energy, Uashington, D.C.

DDE-STD-3009-94, 1996, Preparation Guide for U.S. Department of Energy Monreactor Muclear Facil ity Safety Analysis Reports, U.S. Department of Energy, Mashington, D.c. MRC, 1989, Standard Format and Content for the Safety Analysis Report for en Independent Spent Fuel Storege Instal lation or Monitored
Retrievghle storage Installation (Dry Storagel. Regulatory Guide 3.48, Rev. 1, U.S. Huclear Regulatory Commission, Mashington, D.C. Regulations, as amended.

Garvin, L. J., 1996, Spent Muclear Fuel Project Path Forward, Muclear Safety Equivalency to Comparable MRC-Licensed Facillities,

WHC-SD-SMF-DB-003, Rev. 2, Uest inghouse Hanford Company, Richland, Mashington.

10 CFR 20, "Standards for Protection Against Radiation," Code of Federal Regulations, as emended.

hMRC, 1974, Design Basis Tornade for Muclear Power Plants, Regulatory Guide 1.76, U.s. Nuclear Regulatory Commission, Mashington, 0.C. U.S. Mucflear Regul atory Comission, Washington, D.C.

NRC, 1981, Standard Revien Porthwest Laboratory, Richland, Mashington. Mashingțon, D.c.

Rev. 2, Westinghouse Hanford Compeny. Richland, Mashington. 
Table 3. Information to be Added to the Final Safety Analysis Report for the Canister Storage Building that is not Required by DOE Order $5480.23^{a}$ or by DOE-STD-3009-94 but is Needed to Implement Nuclear Safety Equivalency. (8 sheets)

\footnotetext{
Section and title fram
DOE-STD-3009-94

Material to be added (source)

Conivent

'Iall Imen, A. M., 1996, Canister Storage Buil ding Matural Phenomena Hazards, WHC-s0-5NF-DB-009, Rev. 4, Mestinghouse Manford Company, Richtand Washington.

"ANSI/ANS, 1992, Design Criteria for en Independent Spent Fuel Storage Installation (Pry Imee), ANS1/AYS-57.9-1992, Mnericen Muclear Society, La Grange Park, Illinois.

and Electronics Engineers, New York, Mew York

LEE, 1987. IEEE Recomended Practice for Installation Design and Installation of Large Lead Storage Batteries for Feneratine Stations and

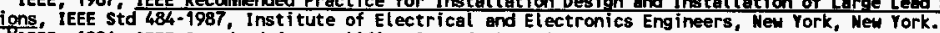

IEEE, 1986, IEEE Standard for Qual ification of Class 1E Lead Storage Batteries for Nuclear Power Generating Stations, IEEE Std 535 -1986, Institute of Electrical and Electronics Engineers, Meu York Mew York. WRC, 1988, Instrument Air Sugoly System Problens Affecting Safety-Related Equipent, Generic Letter 88-14, U.S. Muclear Regulatory Commi ssign, Washington, D.C. NRC, 1989, Safety-Related (1) Motor-Operated Valve Testing and surveill ance, Generic Letter s9-10, U.S. Muclear Reoulatory Conimission, Washingtgn, D.C. Uashington, D.C. Service Mater Systen Problens Affextin. Safety-Related Ecuipment, Generic Letter 89-13, U.S, Muclear Reoulatory Comission,

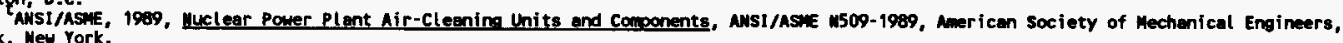

Wew York ANSI/ASME, 1989, Iesting of Muclear Air Ireatment SYstems, AMSI/ASHE W510-1989, Mmerican Society of Mechenical Engineers, New York, ANSI/ANS, 1992, Desion Reguirenents for Light Water Reactor Fuel Handl ing System, AMSI/ANS-57.1-1992, American Muclear Society, La Grange Park, Iljinois.

ANSI/ANS, 1983, Niericen Mational Standard Design Reavirenents for Light Mater Reactor spent fuel storage facilities at Muclear Pouser

Plants, eNSI/ANS-57.2-1983, American Nuclear Society, La Grange Park, Illinois.

DOE Order 6430.1A, 1989, General Desion Criteria, U.S. Department of Energy, Mashington, D.C.

YANSI/ANS, 1986, Criticality Accident Alarm Systein, ANSI/ANS-8.3-1986, ARericen Nuclear Society, La Grange Park, Illinois.

$\mathbf{Z}_{\text {NRC, }}$ 1988, Criticality Accident Alam Systems, Regulatory Guide 8.12, U.s. Nuclear Regulatory Comission, Ueshíngton, D.C.

Aa 10 CFR 835, "occupational Radiation Protection," Code of Federal Requilations, es Rended.

bb WRC, 1978, Informstion Relevant to Ensuring that Occupational Radiation Exposures at Wuclear Pouer Stations uill be as Low as is

Reasonably Achievable, Regulatory Guide 8.8, Rev. 3, U.S. Nuclear Regulatory Conmission, Washington, D.C.

dd 10 CFR 70, "Domestic Licensing of Special Nuclear Material, " Code of Federal Requlations, es enended.

Ce Order 5480.7A, 1993, Fire Protection, U.S. Depertment of Energy, Washington, D.C. Washington, D.C. Uashington, D.C.

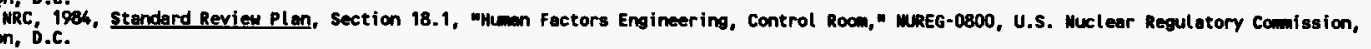


Table 4. Items of Regulatory Guide $3.26^{\text {* }}$ that are Unique to Fuel Conditioning. (6 sheets)

\begin{tabular}{|c|c|c|}
\hline $\begin{array}{l}\text { Section and title } \\
\text { from Regulatgry } \\
\text { Guide } 3.26^{8}\end{array}$ & Item unique to fuel conditioning & $\begin{array}{l}\text { Cold Vacum Drying Facility Safety } \\
\text { Anatysis Report section and title }\end{array}$ \\
\hline 1.1 Introduction & Describe the type and exposure of the fuel to be conditioned. & Execut ive sumbery \\
\hline $\begin{array}{l}1.3 \text { General Process } \\
\text { Description }\end{array}$ & $\begin{array}{l}\text { Include a summary description of the process to be used, including process } \\
\text { origin and background. Ident ify basic material flow and balance for the } \\
\text { product and waste streans. Provide sufficient detait in the discussion and } \\
\text { accompanying charts and tables to provide an understanding of the processes } \\
\text { involved. }\end{array}$ & Section 2.5, Process Description \\
\hline $\begin{array}{l}\text { 4.1 Purpose of } \\
\text { Plant }\end{array}$ & $\begin{array}{l}\text { Describe in general terms the plant, its functions and operation, process } \\
\text { capacity, type of feed, and products. }\end{array}$ & Section 2.5, Process Description \\
\hline 4.1.1 Plant Feed & $\begin{array}{l}\text { Provide a detailed description of the physical, chemical, and radiological } \\
\text { characteristics of the spent fuel to be processed in the plant. Include feed } \\
\text { specifications, such as fissile material limits, forms of the materiat, and } \\
\text { packaging. Presentation of radioactivity characteristics should include } \\
\text { irradiation history, minimun cooling time at receipt, time to processing, and } \\
\text { fission product concentrations. }\end{array}$ & Section 2.5. Process Description \\
\hline $\begin{array}{l}\text { 6.1.2 Plant } \\
\text { Products and } \\
\text { Byproducts }\end{array}$ & $\begin{array}{l}\text { Identify the products and byproducts that will result from plant operation. } \\
\text { Include product characteristics and apecifications. }\end{array}$ & Section 2.5, Process Description \\
\hline $\begin{array}{l}4.1 .3 \text { facility } \\
\text { Functions }\end{array}$ & $\begin{array}{l}\text { Provide information related to the overall functioning of the plant as a } \\
\text { reprocessing operation. Include onsite waste processing, waste disposal or } \\
\text { holding areas, transportation, and utility and water suppl ies. }\end{array}$ & Section 2.5, Process Description \\
\hline $\begin{array}{l}\text { 4.3.2.1 Conf inement } \\
\text { Barriers and } \\
\text { Systems }\end{array}$ & 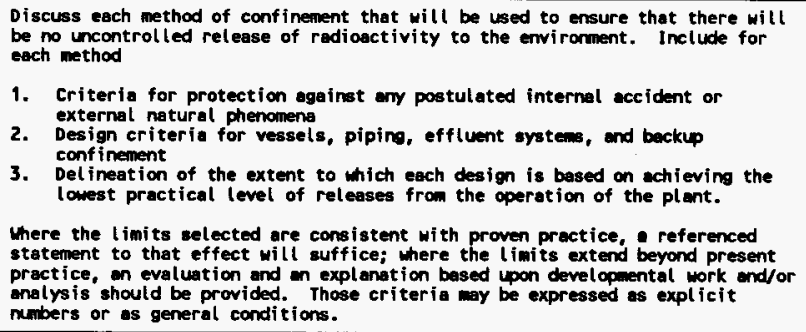 & $\begin{array}{l}\text { Section } 2.6 \text {, Conf inement system } \\
\text { These requirements are more specific } \\
\text { than those required of DOE-STD-3009-96 } \\
\text { for section } 2.6 \text {. }\end{array}$ \\
\hline $\begin{array}{l}\text { 4.3.8 Industrial } \\
\text { and Chemical Safety }\end{array}$ & $\begin{array}{l}\text { Any specific design criteria should be described that are important to } \\
\text { personnel and plant safety. Effects of various industrial accidents should be } \\
\text { presented (e.g., fire, explosion), os well as hazardous chenical reactions } \\
\text { (e.g.. vigorous chemical reactions, hydrogen explosions). }\end{array}$ & $\begin{array}{l}\text { The Ident ification of specific design } \\
\text { criteria is required by DOE-STD-3009-94 } \\
\text { for Section } 8.2 \text {. The evaluation of the } \\
\text { effects of various hazards is required } \\
\text { by DOE-STD-3009-94 for Section 3.3.2. }\end{array}$ \\
\hline
\end{tabular}


Table 4. Items of Regulatory Guide $3.26^{\text {a }}$ that are Unique to Fuel Conditioning. (6 sheets)

\begin{tabular}{|c|c|c|}
\hline $\begin{array}{l}\text { Section and title } \\
\text { from Regulatory } \\
\text { Guide } 3.26^{8}\end{array}$ & I tem unique to fuel conditioning & $\begin{array}{l}\text { Cold Vecum Drying Facility Safety } \\
\text { Analysis Report section and title }\end{array}$ \\
\hline 4.5 Decommissioning & $\begin{array}{l}\text { As required by } 10 \text { CFR Part } 500^{C} \text { Appendix F, MPolicy Relating to the siting of } \\
\text { Fuel Reprocessing Plants ond Related Waste Managenent Facilities, " arrangenents } \\
\text { must be included for safe decommissioning of the plant. Provide in this } \\
\text { gection the design criteria incorporated in the plant for fulfilling this } \\
\text { requirement. Discuss the design philosophy to be used to allow ease of } \\
\text { facility decontanination and future isolation of all radioactive materials from } \\
\text { the public while maximizing the land orea returned to the public domain. }\end{array}$ & $\begin{array}{l}\text { These requirements are sinifar to those } \\
\text { required of DOE-sTD-3009-94 for } \\
\text { Chapter } 16 \text {, "Provisions for } \\
\text { Decontanination and Decomissioning." }\end{array}$ \\
\hline $\begin{array}{l}5.4 .11 \text { Cold } \\
\text { Chemical Systens }\end{array}$ & $\begin{array}{l}\text { Where hazardous chemicals or materials are involved, discuss the provisions } \\
\text { that will be made to mitigate accidents. Itemize the chemicals and materials } \\
\text { that will be used, their quantities, and were they will be used, and codify } \\
\text { with respect to hazard. }\end{array}$ & $\begin{array}{l}\text { Provisions to mitigate hazardous } \\
\text { materials accidents are required by } \\
\text { poE-sTo-3009-94 for Section } 3.3 .2 \text { when } \\
\text { the hazard is identified as having an } \\
\text { unacceptable risk. The standard } \\
\text { requires that section } 8.6 \text { provide a } \\
\text { discussion of hazard el inination and } \\
\text { control for other risks not evaluated as } \\
\text { specific accidents. Section } 8.6 \text { must } \\
\text { lso provide a deseription of the } \\
\text { process for the identification and } \\
\text { evaluation of hazards. }\end{array}$ \\
\hline $\begin{array}{l}5.5 \text { I tems Requiring } \\
\text { further Development }\end{array}$ & 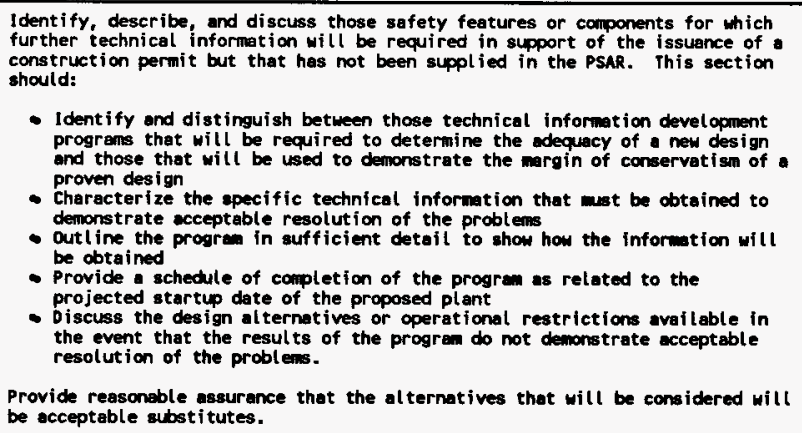 & $\begin{array}{l}\text { These requirenent ore sinilar to those } \\
\text { that would be required of } \\
\text { DOE-STD-3009-94 for section 3.3.2.3.1 } \\
\text { for a new facility. }\end{array}$ \\
\hline $\begin{array}{l}6.1 .1 \text { Marrative } \\
\text { Descript ion (of } \\
\text { Process Systens) }\end{array}$ & $\begin{array}{l}\text { Describe the proposed process and relate it to the equipment and associated } \\
\text { controls. Incluce in this discussion ancillary activities as pertinent to the } \\
\text { use of the main process (i.e. preparation of reactants, of gas handl ing, } \\
\text { volune reduction of wastes, and decontanination). In the description, identify } \\
\text { the interfaces between systens and discuss the safety aspects of the } \\
\text { interfaces. }\end{array}$ & Section 2.5, Process Description \\
\hline
\end{tabular}


Table 4. Items of Regulatory Guide $3.26^{\mathrm{a}}$ that are Unique to Fuel Conditioning. (6 sheets)

\begin{tabular}{|c|c|c|}
\hline $\begin{array}{l}\text { Section and title } \\
\text { from Regulatgry } \\
\text { Guide } 3.26\end{array}$ & I tem unique to fuel conditioning & $\begin{array}{l}\text { Cold Vecum Drying Facility Safety } \\
\text { Analysis Report section and title }\end{array}$ \\
\hline $\begin{array}{l}6.1 .2 \text { Flowsheets } \\
\text { (for Process } \\
\text { Systems) }\end{array}$ & 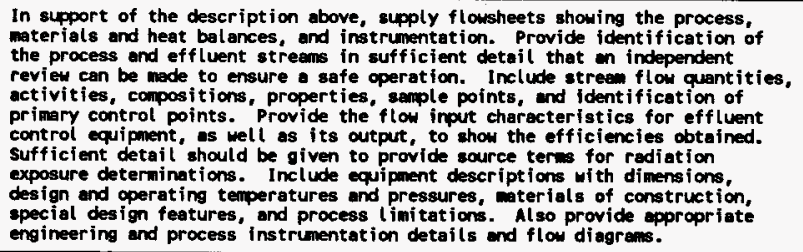 & Section 2.5, Process Description \\
\hline $\begin{array}{l}6.1 .3 \\
\text { Ident ification of } \\
\text { Items for Safety } \\
\text { Analysis Concern }\end{array}$ & $\begin{array}{l}\text { Provide identification of areas or items for safety analys is concern. } \\
\text { Reference this part of the chapter, as applicable, in subsequent discussion of } \\
\text { design and operating features and i tems discussed in chapter 2.0. "Sumbery } \\
\text { Safety Analysis." }\end{array}$ & $\begin{array}{l}\text { These requi rement are similar to those } \\
\text { that would be required of } \\
\text { DOE-STD-3009-94 for Section 3.3.2.3.1 } \\
\text { for a new facility. }\end{array}$ \\
\hline $\begin{array}{l}6.1 .3 .2 \text { Chenical } \\
\text { Safety }\end{array}$ & $\begin{array}{l}\text { Provide a summary description of the principal chemical hazards (hydrogen, red } \\
\text { oil, solvent f(anmability, flworine) and the spproaches used to preclude } \\
\text { associated accidents. }\end{array}$ & $\begin{array}{l}\text { This requi rement is similar }{ }^{\text {to }} \text { that } \\
\text { required of DoE-sTD- } 3009-94 \text { for } \\
\text { Chapter } 8 \text {, "Hazardous and Material } \\
\text { Protection." }\end{array}$ \\
\hline $\begin{array}{l}\text { 6.1.3.3 Process } \\
\text { Shutdoin Modes }\end{array}$ & $\begin{array}{l}\text { Describe the general plant conditions and surveil lence needs in various } \\
\text { shutdown modes--extended, short-term, energency. Indicate the time requi red to } \\
\text { shut down and start up for each mode. }\end{array}$ & Section 2.5, Process Description \\
\hline $\begin{array}{l}6.1 .3 .4 \\
\text { Instrumentation }\end{array}$ & $\begin{array}{l}\text { Provide o summary description of the instruments used to detect process } \\
\text { conditions and the systems used to control the process. The description should } \\
\text { include testability, redundancy, and failure conditions. Also, describe } \\
\text { effluent ond process monitors and deta logger. }\end{array}$ & Section 2.5. Process Description \\
\hline $\begin{array}{l}\text { 6.1.3.5 Remote and } \\
\text { Contact Maintenance } \\
\text { Techniques }\end{array}$ & $\begin{array}{l}\text { Diseuss the rationale and outline the techniques to be used for remote and } \\
\text { contact waintenance. This should include statentent of the cells where the } \\
\text { techniques apply. Include system and component apares. }\end{array}$ & \\
\hline $\begin{array}{l}\text { 6.3.1 Fuel } \\
\text { Receiving, Storage, } \\
\text { Handl ing, and } \\
\text { Transfer }\end{array}$ & $\begin{array}{l}\text { Describe the systens associated with fuel receipt. From the design criteria, } \\
\text { present the provisions for cooling, maintaining fuel essenblies in subcritical } \\
\text { form, and shielding. }\end{array}$ & $\begin{array}{l}\text { Section 2.5, Process Description } \\
\text { Doe-sTD-3009-96 requires that } \\
\text { Section } 6.4 \text { provide a discussion of the } \\
\text { controls requi red to prevent } \\
\text { critical ity. The standerd requires that } \\
\text { Chapter } 8 \text { address rediological } \\
\text { protection burt does not specifically } \\
\text { require a discussion of the provisions } \\
\text { provided for shielding. }\end{array}$ \\
\hline
\end{tabular}


Table 4. Items of Regulatory Guide $3.26^{\circ}$ that are Unique to Fuel Conditioning. (6 sheets)

\begin{tabular}{|c|c|c|}
\hline $\begin{array}{l}\text { Section and title } \\
\text { from Regulatory } \\
\text { Guide } 3.26 \text { a }\end{array}$ & Item unique to fuel conditioning & $\begin{array}{l}\text { Cold Vacum Drying Facility Safety } \\
\text { Analysis Report section and title }\end{array}$ \\
\hline $\begin{array}{l}\text { 6.4.1.3 Design } \\
\text { Description }\end{array}$ & $\begin{array}{l}\text { Discuss the design bases, including materials of construction; pressure and } \\
\text { tenperature limits; detal led dimensions, especially as related to criticality } \\
\text { consideration if not discussed elsewhere; corrosion al lowances; and standards } \\
\text { or codes used. Itemize material and fabrication specifications pertaining to } \\
\text { the system in sufficient detail to relate to the Qual fity Assurance Program. } \\
\text { Include such itens as material of construction, identification, essembly, } \\
\text { welding, installation, and testing. }\end{array}$ & Section 2.5, Process Description \\
\hline $\begin{array}{l}6.4 .1 .4 \text { Safety } \\
\text { Criteria and } \\
\text { Assurance }\end{array}$ & 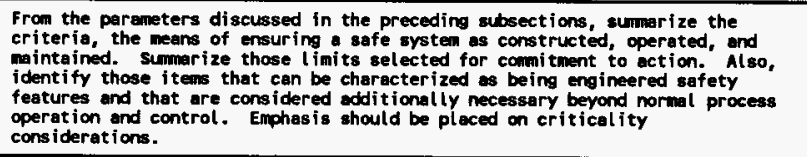 & Section 2.5, Process Description \\
\hline $\begin{array}{l}\text { 6.4.1.5 operating } \\
\text { Limits }\end{array}$ & $\begin{array}{l}\text { Identify limits, conditions, and performance requirements in sufficient detail } \\
\text { to make possible on evaluation as to whether e technical specification may be } \\
\text { necessary. The interface relationship to other systems should be clearly } \\
\text { described. }\end{array}$ & Section 2.5, Process Description \\
\hline $\begin{array}{l}6.4 .2 \text { Component/ } \\
\text { Equipment Spares }\end{array}$ & 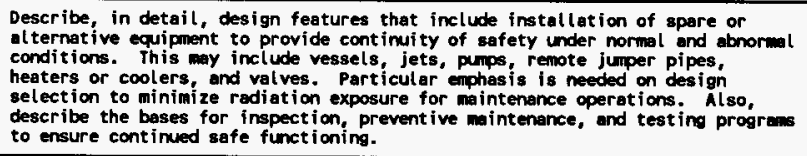 & Section 2.5, Process Description \\
\hline $\begin{array}{l}6.5 \text { Process Support } \\
\text { systens }\end{array}$ & $\begin{array}{l}\text { Al though effluent handling systems may be considered process support, provision } \\
\text { is mode to discuss these elsewhere. To the extent a system is designed for } \\
\text { complete recycle within the main process, it should be discussed in this } \\
\text { section. Describe ony cold chenical systems that will supply or regenerate } \\
\text { reactants being used. Principel ouxiliary beckup oquipment is to be discussed } \\
\text { el sewhere. }\end{array}$ & Section 2.5, Process Description \\
\hline
\end{tabular}


Table 4. Items of Regulatory Guide $3.26^{\circ}$ that are Unique to Fuel Conditioning. (6 sheets)

\begin{tabular}{|c|c|c|}
\hline $\begin{array}{l}\text { Section and title } \\
\text { from Regulatory } \\
\text { Guide } 3.26^{\mathrm{a}}\end{array}$ & Iten unique to fuel conditioning & $\begin{array}{l}\text { Cold Vacum Drying Facility Safety } \\
\text { Analysis Report section and title }\end{array}$ \\
\hline $\begin{array}{l}6.5 .1 \\
\text { Instrumentetion and } \\
\text { Control Systeis }\end{array}$ & 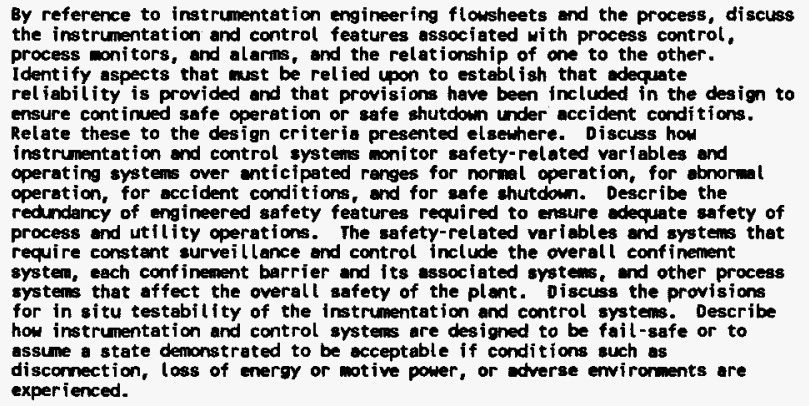 & Section 2.5, Process Description \\
\hline $\begin{array}{l}6.5 .2 \text { System and } \\
\text { Component Spares }\end{array}$ & $\begin{array}{l}\text { Describe in detail installation of spare or al ternative instrumentation } \\
\text { designed to provide continuity of operation under normal and abnormal } \\
\text { conditions. Also, describe the bases for inspection, prevent ive maintenence, } \\
\text { and testing progreas to ensure continued safe functioning. }\end{array}$ & Section 2.5, Process Description \\
\hline 6.6 Control Room & $\begin{array}{l}\text { Discuss how a control room and/or control areas are to be designed to permit } \\
\text { occupency and actions to be taken to operate the plant safely under normal } \\
\text { conditions and to maintain the plant in a safe condition under accident or } \\
\text { other abnormal conditions. Describe the redundancy that allows the plant to be } \\
\text { put into a safe condition if any control room or control orea is removed from } \\
\text { service. }\end{array}$ & Section 2.5, Process Description \\
\hline $\begin{array}{l}\text { 6.7 Sampl ing-- } \\
\text { Analytical }\end{array}$ & $\begin{array}{l}\text { Discuss provisions for obtaining semples for process analysis and control } \\
\text { necessary to ensure that operations are within prescribed limits. Describe the } \\
\text { facilities and analytical equipnent that will be available to perform the } \\
\text { analyses, os well as the destination of taboratory wastes. }\end{array}$ & Section 2.5, Process Description \\
\hline $\begin{array}{l}6.8 \text { Product } \\
\text { Mendl ing }\end{array}$ & $\begin{array}{l}\text { For the product or products resulting from operation of the reprocessing plant, } \\
\text { provide the details of the system and the methods that will be used for their } \\
\text { handling and storage. }\end{array}$ & Section 2.5, Process Description \\
\hline $\begin{array}{l}6.8 .2 .4 \text { Safety } \\
\text { Criteria and } \\
\text { Assurance }\end{array}$ & $\begin{array}{l}\text { Describe all safety-related feetures, systens, and special techniques to be } \\
\text { employed to ensure the safety of the operation. Include systems needed for } \\
\text { criticality control and radiological safety. }\end{array}$ & Section 2.5, Process Description \\
\hline $\begin{array}{l}6.9 \text { Items Requiring } \\
\text { Further Development }\end{array}$ & $\begin{array}{l}\text { Present in the PSaR the details for each item requiring the development of } \\
\text { additional information or data. Identify the item, what is needed, and how and } \\
\text { wen the information will be obtained. Indicate times when data are expected } \\
\text { to be available and options that are available in the event satisfactory } \\
\text { results are not obtained. }\end{array}$ & $\begin{array}{l}\text { These requirenent are similar to those } \\
\text { that would be required in } \\
\text { DOE-sTo-3009-94 for section } 3.3 .2 .3 .1 \\
\text { for a new facility. }\end{array}$ \\
\hline
\end{tabular}


Table 4. Items of Regulatory Guide $3.26^{\mathrm{a}}$ that are Unique to Fuel Conditioning. (6 sheets)

\begin{tabular}{|c|c|c|}
\hline $\begin{array}{l}\text { Section and title } \\
\text { from Regulatory } \\
\text { Guide } 3.26^{2}\end{array}$ & Item unique to fuel conditioning & $\begin{array}{l}\text { Cold Vacum Drying Facility Safety } \\
\text { Analysis Report section and title }\end{array}$ \\
\hline $\begin{array}{l}8.1 .2 \text { Design } \\
\text { Considerations }\end{array}$ & $\begin{array}{l}\text { Discuss the arrangenent and plans for decontamination of the plant as referred } \\
\text { to in } 10 \mathrm{CFR} \text { Part } 50 \text {, Appendix F, "Policy Relating to the siting of Fuel } \\
\text { Reprocessing Plents and Related Waste Management Facilities." }\end{array}$ & $\begin{array}{l}\text { These requirenents, are similar to those } \\
\text { of DOE-5TD-3009-94 for Chapter } 16 \text {, } \\
\text { mprovisions for Decontenination and } \\
\text { Decomissioning." }\end{array}$ \\
\hline $\begin{array}{l}11.5 .2 .2 \text { Technical } \\
\text { Conditions and } \\
\text { Characteristics }\end{array}$ & $\begin{array}{l}\text { Technical conditions and characteristics should be stated in terms of allowable } \\
\text { quantities (e.g., temperature, pressure, mass of fissionable material in } \\
\text { certain systems, concentration of radioact ive material in certain systems, } \\
\text { volume of fluid required in a systen, chemical constitution of certain fluids, } \\
\text { or allowable configuration of equipment). }\end{array}$ & $\begin{array}{l}\text { These requi rentents, are similar to those } \\
\text { of DoE-5TD-3009-94 for Chapter } 5 \text {, } \\
\text { Derivation of Technical Safety } \\
\text { Requi rements, to the extend that the } \\
\text { requi rements relete to the protection of } \\
\text { publ ic heal th ond safety. }\end{array}$ \\
\hline
\end{tabular}

"NRC, 1975, Standard Format and Content of Safety Analysis Reports for fuel Reprocessing Plants, Regul atory Guide 3.26, U.S. Muclear Regulatory Cormission, Washington, D.C.

DOE-STD-3009-94, 1994, ereperation Guide for U.S. Department of Energy Monreactor Muclear Facillity Safety Analysis Reports, U.S. Department of Energy, Hashington, 0.C.

E10 CFR 50, "Domestic Licensing of Production and Utilization Facilities," Code of federal Regulations, as amended.

PSAR = preliminary safety analysis report. 
Table 5. Information to be Added to the Final Safety Analysis Report for the Cold Vacuum Drying Facility that is not Required by DOE-STD-3009-94 and that is Unique to the Conditioning Process. (3 sheets)

\begin{tabular}{|l|}
\hline $\begin{array}{l}\text { section and title from } \\
\text { DOE-5TD-3009-94 }\end{array}$ \\
\hline $\begin{array}{l}\text { Executive Sumnary and } \\
\text { Section 2.3, Facility } \\
\text { Overview }\end{array}$ \\
\hline Section 2.5, Process
\end{tabular}

Description Describe the type and exposure of the fuel to be conditioned.

\section{Material to be included}

Provide a detailed description of the physical, chenical, and radiological characteristics of the spent fuel to be conditioned or provide reference for this information. Include feed specifications, such os fissile material limits, fission product concentrations, forms of the material, packaging, and irradiation history.

Include a sumary description of the conditioning process to be used, including process origin and background. Identify process capacity, basic material flow and balance for the feed and product, and waste streans. For the the wethods that will be used for their hendling and storage.

Discuss support systems, the interfaces between these systens, oncillary activities, and the main process.

Identify the products, including the product characteristics and specifications, and byproducts that result from the plant operation. Provide informetion related to onsite waste processing, waste disposal or holding areas, transportation, and utility and water supplies.

Describe the general plant conditions and surveillance needs in various shutdown modes--extended, short-term, and emergency. Indicate the time required to shut down and start up for each mode. Discuss how control room and/or control areas are to be designed to permit occupancy and actions to be taken to operate the plant safely under normi conditions and to maintain the plant in a safe condition under eccident or other thermal conditions.

Discuss the process design beses, including materials of construction, pressure and tenperature liats, and detailed dimensions.

Provide a summary description of the instruments used to detect process conditions and the systems used to control the process. For safety class instruments, the description should include testability, redundancy, and failure conditions.

Discuss the instrumentation and control features associated with process control, process monitors, and alarms, and the retationship of one to the other. Identify aspects that must be relied upon to ensure cont inved ale operation or safe shutdown under accident conditions. Describe the redundancy of any safety- class features. Discuss the provisions for in situ testability of any safety-class instrumentation and control systens. Describe how such instrumentation acceptable if conditions such es discomection. loss of eneroy or motive power, or adverse environivents are experienced.

Describe in detail installation of spare or alternative safety-cless instrumentation designed to provide continuity of operation under normal and abnormal conditions. Also, describe the bases for inspection. preventive maintenance, and testing programs to ensure continued safe functioning.

Discuss provisions for obtaining sapples for process analysis and control necessary to ensure that operations are within prescribed limits. Describe the facilities and analytical equipment that will be available to perform the analyses, as well is the destination of laboratory wastes.

Provide assurance that sharing of comion utilities and services and physical interaction between the CVDF and other facilities do not impair the capability of either facility to perform its gafety functions (Note: The consideration for sharing of structures is to be discussed in section 2.4 , "Facility structure." ") (Garvin 19\%6) 


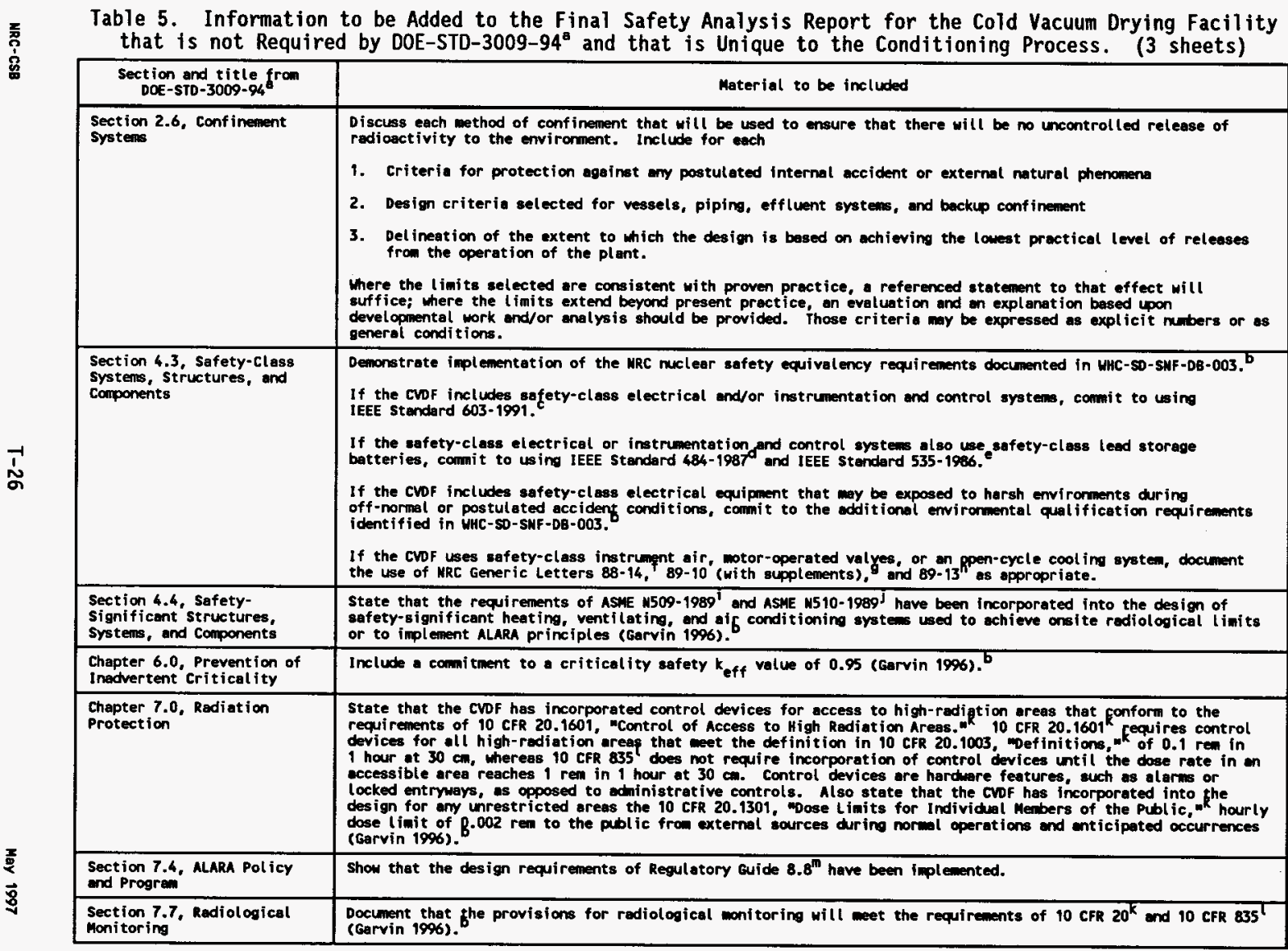


Table 5. Information to be Added to the Final Safety Analysis Report for the Cold Vacuum Drying Facility that is not Required by DOE-STD-3009-94 and that is Unique to the Conditioning Process. (3 sheets)

\begin{tabular}{|c|c|}
\hline $\begin{array}{l}\text { Section and title from } \\
\text { DOE-STD-3009-94 }\end{array}$ & Material to be included \\
\hline $\begin{array}{l}\text { Chapter } 8 \text {, Radiation } \\
\text { Protection }\end{array}$ & Discuss the provisions provided in the facility to timit rediological exposure by shielding. \\
\hline $\begin{array}{l}\text { Section 11.4, fire } \\
\text { Protection }\end{array}$ & 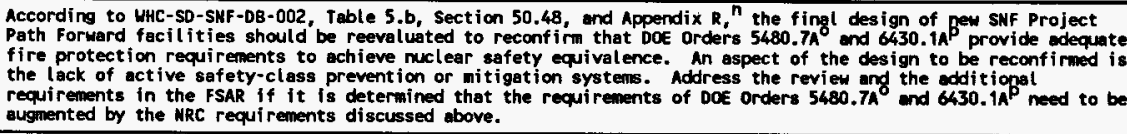 \\
\hline Chapter 13.0, Human Factors & 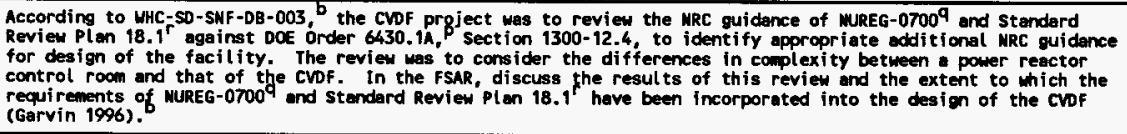 \\
\hline
\end{tabular}

QDOE-STD-3009-94, 1994, Preparation Guide for U.S. Department of Eneray Honreactor Nuclear Facility Safety Analysis Reports, U.S. Depertment of Energy, Washington, D.c.

Company, Richland, Washington.

C I Y Richland, Washington.

Electronic Engineering, Piscataria for Safety for Muclear Power Generating Stations, IEEE Standard 603-1991, Institute of Electrical end

IEEF, 1987 , Recomentersey.

Substation, IEEE Standard 484-1987. Institute of Etion Design and Installation of Large Lead Storage Batterfes for Generating Stations ond

tations, IEEE Standard 484-1987, Institute of Electrical and Electronic Engineering, Piscataway, New Jersey.

Electical and El ectronic Engineering, Piscataway, New Jersey icries for Muclear Power Generating Stations, IEEE Standard 535-1986, Institute of f

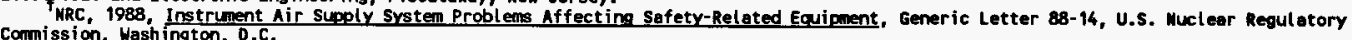

MRC, 1989, Safety-Related Motor-Operated Valve Testing and Surveillance, Generic Letter 89-10, U.S. Muclear Regulatory Conmission, Washingtón, D.c.

MRC, 1989, Service Uater System Problems Affecting Safety-Related Equipment, Generic Letter 89-13, U.S. Muclear Regulatory Conmission,

Uashingtón, D.C

ASME, 1989, Muclear Power Plant Air-Cleaning Units and Components, Astre M509, Mmerican Society of Mechanical Engineers, Mew York, Mew York.

ASME, 1989, Iesting of Nuclear Air Treatment Systems, ASME W510 (R95), American Soci ety of Mechanical Engineers, Mew York, New York.

10 CFR 20, "Standards for Protection Against Radiation," Code of Federal Regulations, as emended.

10 CFR 835, moccupational Radiation Protection," Code of Federal Regulations, is anended.

WRC, 1982, Information Relevant to Ensuring that Dccupational Radiation Exposures at Nuclear Power Stations nill be as Low as is Reasongbly

Achievable, Regulatory Guide 8.8, Rev. 1 (proposed), U.S. Nuclear Regulatory Connission, Washington, D.C.

WHC-Garvin, L. J., 19\%, Spent Muclear fuel Project Path Forward, Nuclear Safety Equivalency to Conparable MRC-Licensed Fecillities,

-SD-SNF-DB-002, Rev. 1, Westinghouse Hanford Company, Richland, Washington.

DOE Order 5480.7A, 1993, Fire Protection, DOE 5480.7A, U.S. Departiment of Energy, Nashington, D.C.

DoE Order $6430.1 A, 1989$, General Design Criteria, DOE 6430.1A, U.S. Department of Energy, Washington, D.C.

Washingtón 1995, Human Systen Interface Desion Reviey Guidelines, MUREG-0700, Rev. 1 (for combent), U.s. Muclear Regulatory Commission, MRC, 1981 , KRC, 1981,
Washington, D.C.

ALARA $=$ as low as reesonably achievable.

CVDF = cold Vacuu Drying Facility.

FSAR = final safety analysis report.

MRC $=$ U.S. Nucleer Regulatory Commission.

SNF = spent nuclear fuel. 
HNF-SD-SNF-SP-012 REV 0

This page intentionally left blank. 


\section{DISTRIBUTION SHEET}

\begin{tabular}{l|l|l}
\hline To & $\begin{array}{l}\text { From } \\
\text { Distribution }\end{array}$ & Page l of 1 \\
\cline { 2 - 3 } & L. J. Garvin/Nuclear Safety & Date $05 / 07 / 97$ \\
\hline Project Title/Work Order & EDT No. 607687 \\
\cline { 2 - 2 } Additional Guidance for Including Nuclear Safety Equivalency in & ECN No. N/A \\
the Canister Storage Building and Cold Vacuum Drying Facility &
\end{tabular}

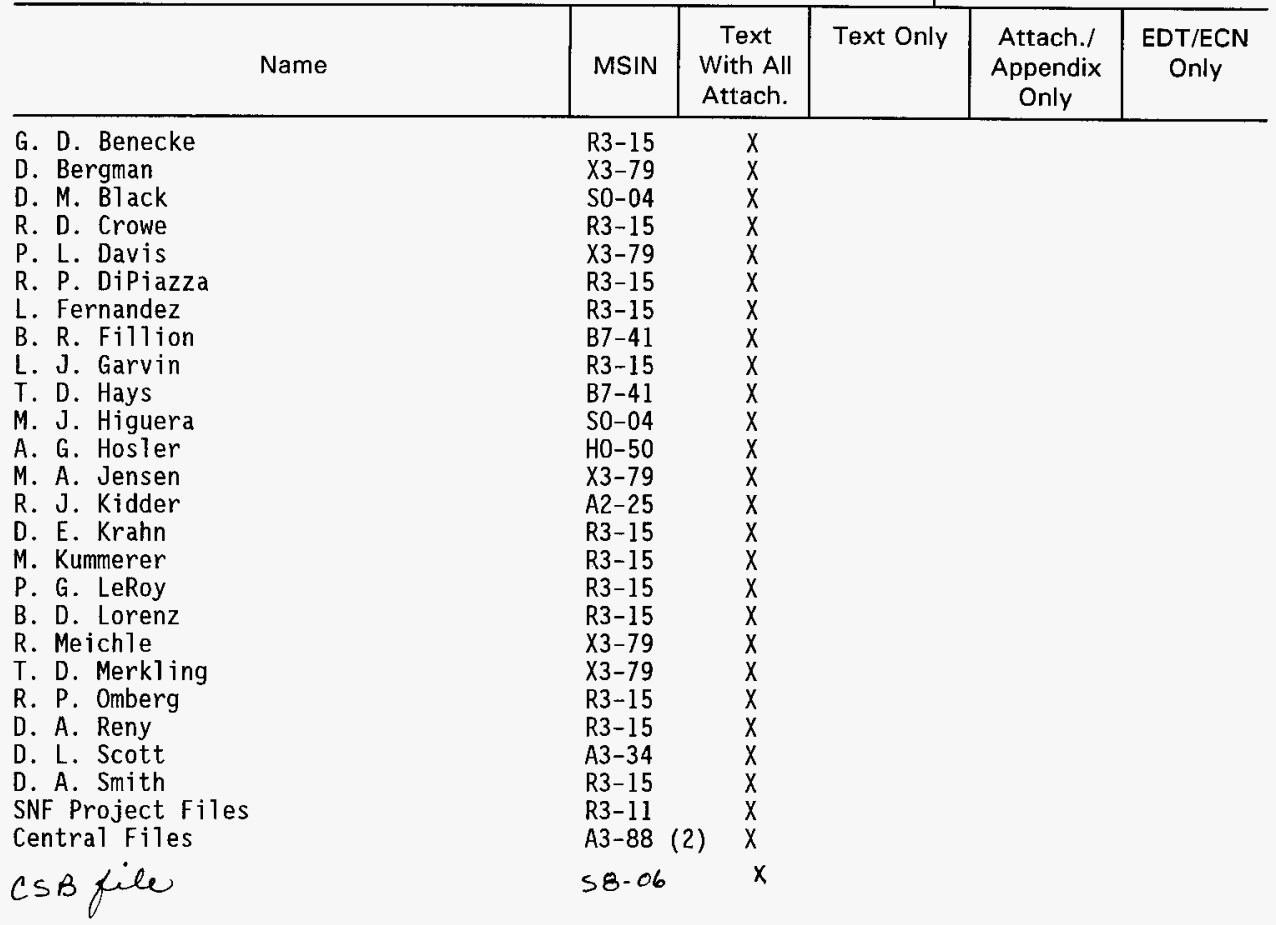

